\title{
Role of Trace Elements in Duchenne Muscular Dystrophy
}

\author{
Sanjeev Kumar' ${ }^{1}$, Reena, Mittal' ${ }^{2}$, Sweety ${ }^{1}$ and D. C. Jain ${ }^{3}$ \\ ${ }^{1}$ Department of Physics, Central Medical Physics Research Laboratory,D.A.V. (P.G.) College, \\ Muzaffar Nagar, U.P. (India). \\ ${ }^{2}$ Deptt. of Mathematics, Shri.K.K.JAIN. College, Khatauli, Distt. Muzaffarnagar, U.P.India \\ ${ }^{3}$ Department of Neurology, Safdarganj Hospital, New Delhi, \\ sanjeev1962kumar@yahoo.co.in; drdcjain@gmail.com; reena_math@rediffmail.com
}

\begin{abstract}
Atomic absorption analysis involves measuring the absorption of light by vaporized ground state atoms and relating the absorption to concentration. The incident beam of light is attenuated by atomic vapour absorption according to Beer's Law. The estimation of trace elements show a colorful presentation of different metals. It has been seen and found that the levels of zinc and selenium were lower in DMD cases in comparison to healthy controls. The elements such as copper, calcium, iron, magnesium, potassium, sodium were found higher than controls. On the basis of statistical analysis we have measured regression and correlation coefficients including multiple correlation coefficients between different trace elements like $\mathrm{Na}, \mathrm{K}, \mathrm{Ca}, \mathrm{Mg}, \mathrm{Zn}, \mathrm{Cu}$, Fe and Selenium in normal samples. A trend has been found in coefficient of correlation such as $r_{\mathrm{CuZn}}>r_{\mathrm{NaK}}>r_{\mathrm{Zn} . \mathrm{Se}}>r_{\mathrm{CuFe}}$ with positive correlation and $r_{\mathrm{ZnFe}}>r_{\mathrm{Fe} . \mathrm{Se}}>r_{\mathrm{Cu} . \mathrm{Se}}>r_{\mathrm{CaMg}}$ with negative correlation. Coefficient of partial correlation is also calculated and found that a trend has been set up between trace elements and given here as $r_{\mathrm{ZnFeCCu}}>r_{\mathrm{ZnCu} . \mathrm{Fe}}>$ $r_{\text {CuFe.Zn }}>r_{\mathrm{NaK} . \mathrm{Ca}}>r_{\mathrm{CaNa} . \mathrm{K}}>r_{\mathrm{CaK} . \mathrm{Na}}>r_{\mathrm{NaK} . \mathrm{Mg}}$ with positive correlation and we have found also a negative correlation between some of the elements and a trend is given here as $\mathrm{rZnFe} . \mathrm{Se}>r_{\mathrm{MgK} . \mathrm{Na}}>r_{\mathrm{MgNa} . \mathrm{K}}$

Multiple correlation coefficient in normal healthy person has been estimated and found that a trend, which is given here as

$$
R_{\mathrm{Zn} \cdot \mathrm{FeCu}}>R_{\mathrm{Fe} . \mathrm{CuZn}}>R_{\mathrm{Cu} . \mathrm{FeZn}}>R_{\mathrm{Zn} \cdot \mathrm{FeSe}}>R_{\mathrm{K} \cdot \mathrm{MgNa}}>R_{\mathrm{Mg} . \mathrm{NaK}}>R_{\mathrm{Na} . \mathrm{MgK}}>R_{\mathrm{K} \cdot \mathrm{NaCa}}>R_{\mathrm{K} . \mathrm{NaCa}}>R_{\mathrm{Ca} . \mathrm{KNa}} .
$$

We have also measured correlation coefficients including multiple correlation coefficients between different types of trace elements like $\mathrm{Na}, \mathrm{K}, \mathrm{Ca}, \mathrm{Mg}, \mathrm{Zn}, \mathrm{Cu}$, Fe and Selenium in DMD samples. A trend has been found in coefficient of correlation such as $r_{\mathrm{CaMg}}>r_{\mathrm{FeZn}}>r_{\mathrm{NaK}}>r_{\mathrm{Cu} . \mathrm{Se}}$ with positive correlation
\end{abstract}


and $\quad r_{\mathrm{Fe} . \mathrm{Se}}>r_{\mathrm{CuFe}}>r_{\mathrm{Zn} . \mathrm{Se}}>r_{\mathrm{CuZn}}$ with negative correlation. Coefficient of partial correlation is also calculated and found that a trend has been set up between trace elements and given here as $r_{\text {CuFe.Zn }}>$ $r_{\mathrm{CaNa} . \mathrm{K}}>r_{\mathrm{MgK.Na}}$ with negative correlation and also found a trend of positive correlation as $r_{\mathrm{ZnFeCl}}>$ $r_{\mathrm{NaK} . \mathrm{Ca}}>r_{\mathrm{ZnFe} . \mathrm{Se}}>r_{\mathrm{NaK} . \mathrm{Mg}}>r_{\mathrm{CaK} . \mathrm{Na}}>r_{\mathrm{MgNa} . \mathrm{K}}$.

Multiple correlation coefficient in DMD patients has been estimated and found that a trend, which is given here as $R_{\mathrm{Fe} . \mathrm{CuZn}}>R_{\mathrm{K} . \mathrm{NaCa}}>R_{\mathrm{Zn} . \mathrm{FeCu}}>R_{\mathrm{Na} . \mathrm{KCa}}>R_{\mathrm{Zn} . \mathrm{FeSe}}>R_{\mathrm{K} . \mathrm{MgNa}}>R_{\mathrm{Cu} . \mathrm{FeZn}}>R_{\mathrm{Na} . \mathrm{MgK}}>R_{\mathrm{Ca} . \mathrm{KNa}}>$ $R_{\mathrm{Mg} . \mathrm{NaK}}$.

Our findings suggest that the values of higher levels of trace elements should be adjusted such that these levels must slight below or equal to the normal limits of the particular element. The levels of zinc and selenium should be maintained within the normal limits for DMD cases in comparison to healthy controls. The elements such as copper, calcium, iron, magnesium, potassium, sodium may be reduced up to the normal limits in comparison to healthy persons.

Key Words: Duchenne muscular dystrophy, Trace elements, Flame atomic absorption, Multiple and partial correlation coefficiments and regression equations

\section{Introduction}

Humans are able to freely move their bodies about muscles, which is a precious, complex physiology that should not taken for granted. There are so many types of muscles in human body like voluntary and involuntary muscles and smooth and strained muscle fibers that all function in a tight realm with the nervous system and different chemical reactions.

Muscles are composed of protein in a highly organized system from large groups to small fibers. Muscle units are separated from other muscle groups by plasma membranes called sarcolemma and the cytoplasm, which is called sarcoplasm. There are long protein bundles within the sarcoplasm called myofibrils. There are so many ATP producing mitochondria, as well as glycogen and myoglobin. Bundles of paralled myofilaments make up the myofibrils where most of the action takes place. There are contractile proteins in the myofilaments, called myosin, and action. The myosin are thic filaments and actin thin filaments, when signald, the action and myosin interlock and slide over each other to stretch or slide into one another for contraction. They are signaled from the nervous system followed by a series of chemical reactions involving ATP, calcium, sodium and potassium ions.

There are many other proteins involved in the process. Abide from the contractile proteins, there are regulatory proteins called tropomyosin and troponin where act like a switch to determine when to contract and where to relax. On the muscle fiber the 'I band' is the space between the myosin (thick) filaments, where lies only the thin filaments. There is a dark disc in the middle of each ' $\mathrm{l}$ ' band called ' $\mathrm{Z}$ disc'. This disc is made of titan. This is connected to sarcolemma by the cytoskeleton. As the muscle contracts the "I band' shrinks and the sarcomere shortens and as the Z disc's come closer together pulling on the sarcolemma shortening the cell. This is how the muscle contracts? 
Sanjeev Kumar, Reena, Mittal, Sweety and D. C. Jain; Role of Trace Elements in Duchenne Muscular Dystrophy, Journal of Biomedical Engineering and Medical Imaging, Volume 1, No 5, Oct (2014) , pp 71-112

One of the most clinically important accessory proteins is dystrophin. This is located just under the sarcolemma in the cytoplasm in the area of the 'I band'. It is produced by specific genes and links the actin filaments to the protein extracellular matrix in the membrane known as the dystrophin associated protein complex.

Elements of the dystrophin gene and the protein structure have been completely identified. The exact functional role is still a bit unclear. It is thought that its primary function is to provide mechanical reinforcement to the structure of the sarcolemma and thereby protecting the membrane from the stress or tearing during contraction. If dystrophin is defective or absent, the membrane breaks down, which then substances and molecules like proteins and enzyme leak out the fibre into circulation. These enzymes and chemicals that leak out are responsible for certain chemical reactions and necessary to produce for muscle contraction. At the same time the extracellular substances leak into the fiber through the broken down membrane damaging the fiber and disrupting the process of muscle contraction and may cause irreparable damage. The absence or abnormality of dystrophin results in a condition known as muscular dystrophy (MD). Muscular dystrophny is a crippling disease resulting from mutated genes, which showly wastes away muscle tissue. It has been seen that without dystrophin to help to protect the fiber membrane keeping it intact, and assisting to create energy, the muscles begin to degenerate and atrophy, being replaced by fat and fibrous scar tissue creating fascia adhesions throughout the body. It is thought that the major determinate of the membrane damage would be the level of stress associated with contraction rather than the number of muscle actions. Petrof, B. et. al. [1] have given their thoughts to explain why it primarily affects the peripheral limbs? Muscular dystrophies most commonly involve in a genetic mutation in the dystrophin genes preventing the production of dystrophin or limiting the amount in subnormal levels. Generally in muscle tissue it has a normal value for small tares on the sarcolemma to occur as the muscle undergoes excessive strain and there are small molecules that enhance the natural repair process.

However in the absence of dystrophin, the sarcolemma is left unprotected tearing more frequently and more easily therefore muscle degeneration greatly out weights muscle regeneration eventually leading to death and adhesion of the tissue.

Emery, A.E. [2] has given his thought regarding muscular dystrophies, which are characterized by progressive irreversible degeneration process, which results in weakness and wasting of muscle tissue. The muscular dystrophies share clinical symptoms. These differ largely in severity, age of onset, and distribution of affected muscle tissue.

The mechanisms responsible for this divergence in pathology are still not identified in detail. It is useful to understand the basic anatomy of the nerve and muscle disorders. The nerve cells have bodies that contain a nucleus. The nucleus contains a genetic material, projection called dendrites that receive information from other nerves, and axons that transmit information to other nerves, ultimately, to muscles. Whether it be the limb, eyes, bladder, bowel, lungs, or heart, all body movements depend on or regulated by the action of nerves on muscle. The brain is made up of billions of nerve cells that communicate with each other by sending information across interconnecting axons and dendrites, i.e., by synapsing. Some nerve cells in the brain have long axons that leave the brain and descend in the spiral cord to synapse with the cell bodies of other nerves, the anterior horn cells, in the spinal cord. These cell bodies are found at each level of the spine. After receiving the information from the brain, 
they send these informations down their axons (peripheral nerves) to communicate synapse with muscles in the limb, head and diaphragm. The axons of limbs peripheral nerves synapse with muscle cells across meet at a junction called myoneural junction.

By definition, neuropathies are diseases of nerves and myopathies are diseases of muscle. After cystic fibrosis, myopathies are the most commonly inherited diseases. Muscular dystrophies are myopathies and tend to progressive, with ongoing degeneration and regeneration of muscle fibers. Spinal muscular atrophy (SMA), amyotrophic lateral sclerosis (ALS) and polio myelitis are essentially diseases of the anterior horn cells of the spine. Bach, R .J.[3] has given views that people with SMA are born with fewer-than normal anterior horn cells of the spine. Neuromuscular diseases are diseases of the peripheral nerves (neuropathies and anterior horn cell diseases), the myoneural junctions (myasthenia gravis), or the muscles (myopathies) themselves can be understood with the detailing of these diseases. These conditions cause muscle weakness but do not affect sensory functions such as the ability to feel objects, see, hear, or smell, nor do they affect the autonomic nervous system that controls bladder and bowl function.

Every cell in the human body has forty eight chromosomes. Forty six chromosomes are autosomes and two are $\mathrm{X}$ or $\mathrm{Y}$ sex chromosomes. Forty six autosomes are twenty three pairs of chromosomes; one in each pair is inherited from each parent. Our entire genetic make-up is determined by the deoxyribonucleic acid (DNA) content of the hundreds of thousands of genes in each of the chromosomes. Defective genes result in many of the neuromuscular diseases.

Recessive diseases require that the abnormal gene by inherited from both parents. When an abnormal gene needs to be present on the autosome inherited from one parent only, the disorder is called autosomal dominant. Thus, neuromuscular diseases inherited from defective genes on autosomes are either autosomal recessive or autosomal dominant disorders. One of about every $40-60$ adults carries the defective gene for SMA on one of his or her two number 5 chromosomes. For a child to inherit SMA, an autosomal recessive disorder, both mother or father must carry the defective gene and transmit it to the child. There is one out of four chance that a child of parent carriers of SMS will inherit the abnormal gene from both parents and develop SMA. There is a fifty percent chance that the child will be a carrier but not develop SMA. There will be twenty five percent chance that the child will neither be a carrier nor develop SMA. Children with SMA must inherit defective genes from both parents. For an autosomal dominant condition like facioscapulohumeral muscular dystrophy, on the other hand, only one parent's affected gene needs to be transmitted. Each patient must have one affected parent, and there is a fifty percent chance of each child inheriting the disease. Neuromuscular disease can also be inherited from defects on the $X$ (Sex) chromosome. Children with sex-linked recessive disorders, such as Duchenne, Becker, and Emery-Dreifus muscular dystrophies, inherit a single defective gene on the $X$ chromosome from the mother and a normal $Y$ chromosome from the father. Because $Y$ chromosome does not have the genetic material to offset the presence of the defect on the X-chromosome, the child inherits the disease. This is called sex-linked recessive disorder.

A female child with a defective $\mathrm{X}$-chromosome from the mother and a normal $\mathrm{X}$ chromosome from the father does not develop the disease. She is a disease carrier who can transmit it to her own male children. When the mother is a carrier, her sons will have a fifty percent chance of being affected, while 
Sanjeev Kumar, Reena, Mittal, Sweety and D. C. Jain; Role of Trace Elements in Duchenne Muscular Dystrophy, Journal of Biomedical Engineering and Medical Imaging, Volume 1, No 5, Oct (2014) , pp 71-112

her daughters will have the same chance of being heterozygous carriers. Mother's male relatives may be affected. A survey has been made and it has been reported in the literature that $70 \%$ of the carriers of the abnormal gene for Duchenne muscular dystrophy (DMD) actually have some degree of muscle weakness.

There are nine kinds of muscular dystrophies. These are classified by the depending on distribution of affected muscle groups, severity and prognosis, genetic defects and the means of inheritance. Duchenne muscular dystrophy is the most common and most severe. It affects not just all the voluntary muscles but also the heart and respiratory muscles as well shortening one's life span drastically. This type of dystrophy is due to genetic mutations on the twenty third chromosome, the sex determining chromosome, being an $\mathrm{X}$ linked recessive or sex-linked recessive trait. Therefore the males are affected from the gene passed down by their mothers. Mother was only a carrier.

Other types of dystrophies are those inherited through X-linked recessive trait are Becker and EmeryDreifuss muscular dystrophy. Becker muscular dystrophy is a different mutuated gene. It is located on the same gene locus as Duchenne. This type of dystrophy affects the heart tissue in general. It is less severe. It has a longer life expectancy. Autosomal dominate trait may inherit in some different types of dystrophies. These are facioscapulohumeral, distal and occulopharyngeal muscular dystrophies as well as myotonic dystrophy. Facioscapulohumeral muscular dystrophy is caused by a missing piece of DNA on chromosome 4. This type of dystrophy affects the face, shoulders and upper arms but later affects certain muscles of the legs, the abdominal and pelvic girdle leading to extreme lordosis which may require a wheel chair. This type of dystrophy rarely affects the heart and respiratory muscles. It cannot short the span of life. The most of this type begins at the age of 20 years. It spreads very slowly due to rapid bursts of muscle deterioration.

Neuropathies and myopathies such as polymyositis and mysthania gravis are due to inflammatory or immunologic disorders that affect muscle. They can also appear in childhood and in many ways resemble inherited neuromuscular diseases. They are acquired rather than inherited conditions. There is no defect in the genes or chromosomes of patient of polymyosis or myasthenia gravis.

We are giving the details of Duchenne muscular dystrophy only because the exact theme of the work is to carry research as the approved and ethically committee cleared topic. We have chosen this topic to study different aspects of the DMD with spectroscopic tools of Science.

Duchenne muscular dystrophy is the most common neuromuscular disease.. A case of DMD was first reported in 1836 in Italy. It was recognized and described as an inherited disorder of boys by the English physician Meryan, E. [4] in 1852. The condition was in appropriately named after 'Duchenne'. Duchenne, G.B.A. [5] was a senior neurologist practicing in Paris. Duchenne was disparaged Meryan's work and first wrote about the condition in 1868. Duchenne at first confused it with cerebral palsy, poliomyelitis, and other conditions.

Although muscle strength may be slightly decreased from birth. Infants with DMD are thought to have no physical problems. It has been reported in the literature that the children with DMD begin to walk at the age of one and half years. Thirty percent children can walk independently before fifteen months of age. Some children can begin to walk only when they are three years old. There is no correlation found between the late walking and rapid progression or severity. 
Muscle weakness is generally first recognized between ages of three and five years. It progress symmetrically and in a predictable pattern. Children tend to walk on their toes. Some children walk up on their toes from outset and are never able to walk with their feet flat. They also tend to waddle and have to climb up their legs, thighs, and hips when getting up from the floor or from the chair. The ability to run, which is generally achieved by two years of age, is not attained.

If the children of DMD are not properly treated they develop an imbalance in muscle strength at every joint. Hip flexors remain stronger than hip extensors. Knee flexors remain stronger than knee extensors. The ankle plantar flexors remain stronger than ankle dorsiflexors. The imbalance in strength at any joint leads to contracture of the joints muscle and soft tissues.

The stronger muscles are shorten. The muscles and their surrounding connective tissues become tight. The joint's range of motion is decreased. The stronger muscles on one side of the joint stretch the weaker muscles on the other side of the joint. This not only causes contracture of the stronger muscles but also makes the weaker muscles get weaker even faster, because they are stretched and no longer at their ideal length for contracting. Severe muscle weakness can prevent ambulation. It has been seen that the children with DMD and other neuromuscular diseases lose the ability to walk prematurely because of joint contractures.

Moser, H. [6] has studied Duchenne muscular dystrophy: Pathogenic aspects and genetic prevention. The author has put forward his views before the medical science as the patients are an wheel chair bound at the age of eight to ten years. The die before the age of twenty years generally. The mutation rate is in the order of $7 \times 10^{-5}$. This rate is higher than for any other X-linked genetic disease. There is no structurally or functionally abnormal protein known that might represent the primary gene product. It has no any pathogenic mechanism leading to the observed biochemical and histochemical alterations been elucidated. The functional defect of the muscular plasma membrane is still most attractive. It would be able to explain both the excess of muscular constituents found in serum of patients and carriers such as creating kinase (CK), as well as the excessive calcium uptake by dystrophic muscle fibres, which, prior to necrosis, could lead to hyper contractions rupture of myofilaments in adjacent sarcomas and by excessive calcium uptake to mitochondrial damage causing crucial energy loss.

Eemery, A. E. [7] and Abood, E. A. et. al. [8] have studied and given their thought as the incidence of DMD is approximately 1 in every 3000.

The first symptoms of DMD are characterized by frequent falling, difficulty of getting up from a standing or lying position and a waddling gait. The calf musculature is significantly enlarged by hypertrophy, fat, infiltration, and accumulation of connective tissue. It has been seen that twenty percent patients of DMD has a mental impairment. Affected skeletal musculature is mainly proximal, and results in wheel chair dependence during the early teenage. Patients die with cardiae failure as an adolescent. Simands, A. K. et. al. [9] have studied DMD and found that infections, leading to pneumonia as a result of lack of ventilation are the cause of death. The care of respiration may increase the survivals. Somer,H. et. al. [10] have studied DMD and found that a major characteristic of DMD and other muscular dystrophies is displayed of muscle necrosis, which results in high serum levels of the isoenzyme creatine kinase (CK). The leaks of CK from affected degeneration myofibers to the blood stream in addition to other enzymes such as perovative Kinase. 
Sanjeev Kumar, Reena, Mittal, Sweety and D. C. Jain; Role of Trace Elements in Duchenne Muscular Dystrophy, Journal of Biomedical Engineering and Medical Imaging, Volume 1, No 5, Oct (2014) , pp 71-112

Mokri, B. et. al. [11] have found that plasma membrane defects are early and basic pathologic alterations and are represented by lesions of various sizes. He also found that there are some ultrastructural abnormalities of the membrane. Engel, J. et. al. [12] have studied regions near small lesions contain dilated endocytotic vesicles, whereas large lesions harbor dilated SR Vesicles, irregularly positioned sarcotubular components depending mitochondria, and small clusters of glycogen.Gillis, T. N. [13] has studied and found that extracellular calcium can enter the myobiber and cause as imbalance of the calcium homeostasis, which results in myofiber degeneration. The imbalance of calcium homeostasis might be that degeneration preludes the extracellular calcium influx. Sandri, M.[14], Tidball J. G.et.al.[15] and Matsuda, R.et.al[16] have studied the degeneration leading to myofiber necrosis, which was initiated via other mechanisms. The detection of apoptotic nuclei demonstrating DNA fragmentation in muscle biopsies from DMD patients. The absence of the DGC leads to sarcolemmal rupture and subsequent leaking of intracellular proteins, which are unknown to the immune system.

Spencer, M. J. et. al. [17] have studied DMD and found that the leaking of intracellular proteins attracts and activates cytotoxic lymphocytes and helper T-cells, which initiate the apoptotic program in ruptures myofibers.

Bradley, W. G. et. al. [18] have studied dystrophin deficiency and found that this deficiency leads to irreversible myofiber cell death or necrosis. The first necrotic myofiber can be demonstrated in the neonatal period. The myobiber at this stage is single. The necrotic myobibers appear in groups of 2-15 myofibers with the increase of age of the patient.

Bowman, W. [19] has studied muscular dystrophy and found that myofiber necrosis is segmental, which means that not the entire myofiber is affected by necrosis. The basal lomina surrounding the necrotic myofiber is not affected. It remains empty shell. The affected myofibers contain membrane attack complexes, which are the result of complement activation. The insertion of this in the sarcolemma creates holes and causes cell-lysis.

The interests of brevity and accuracy are both properly served by a simple statement that we do not know the etiology of DMD. There has been so much discussion in the last few years challenging the traditional concept of muscular dystrophy as a primary illness of the muscle. Murphy, D. L. et. al. [20] have given their views regarding the search for abnormalities in catecholamine metabolism and it was accelerated by the findings that there was a reduced initial rate of accumulation of serotonin in platelets from the DMD patients.

Paulson, O. F. et. al. [21] have studied blood flow in muscle of DMD patients and could not find any abnormality. Jerusalem, F. et. al. [22] have studied electron microscopic and morphometric studies of the capillaries in muscle from patients with the disease have been unrevealing.

Mc Comas, A. J. et. al. [23] have suggested that the muscle fibers in Duchenne muscular dystrophy were not being lost in a random fashion but disappearing in groups associated with the loss of motor units. They also proposed that DMD might have its origin in the malign influence of a sick motor neuron upon the muscle fibers.

Panayiotopoulos, C. P. et. al. [24] and Ballantyne, J. P. et. al. [25] have studied DMD and could not find any abnormality in the muscle fibers. The disease may be associated with an abnormal neural influence. 
Matheson, D. W. et. al. [26] have studied the changes in the behaviour of different cell membranes and critically described the DMD and concluded that an abnormal surface deformation of erythrocytes produced by washing the red blood cells of DMD patients in saline.

Miale, T. D. et. al. [27] and Miller, S. E. et. al. [28] have studied DMD patients and could not attain the results of Matheson, D. W. et. al. [26] and proposed that it may be a non-specific outcome of Matheson, D. W. et. al. [26] work.

The behaviour of some of the enzymes, which are associated with sarcolemmal or erythrocyte membranes are anomalous.

Brown, H. D. et. al. [29] have studied the activity of $\mathrm{Na}, \mathrm{K}, \mathrm{ATPase}$ of erythrocyte membranes in DMD found that this is stimulated by ouabain, rather than being inhibited as in the normal situation.

Peter, J. B. et. al. [30] have shown that a factor present in the serum of DMD patients may contribute to the alteration given by Brown, H. D. et. al. [29]. Roses, A. D. et. al. [31] have studied endogenoces phospnorylation of a group of membrane proteins. This protein activity is called as protein Kinase activity and it is found abnormal high in erythrocyte membranes.

Mawatari, S. et. al. [32] have studied adenyl cyclase which is an enzyme and it is found to be abnormal. It is associated with sarcolemmal membranes. The enzyme is stimulated by epinephrine and sodium fluoride but in DMD patients this stimulation is less than normal .Most of the efforts in carrier detection have been directed to the detection of subclinical abnormalities. Muscle biopsy can be done. Pearce, G. W. et. al. [33] and Roy, S. et. al. [34] have studied muscle biopsies in DMD patients and one may see foci of necrotic fibers, moth eaten and whorled changes in intermyfibrillar network pattern. The internal nuclei are in abnormal number. These changes were also found in normal healthy persons. These patients are not carriers and the gastro enemius muscle is biopsied. Their changes are found in patients who are at the risk. This is the strong presumptive evidence of the carrier state.

Ionasescu, V. et. al. [35] have found an abnormality in ribosomal protein synthesis of DMD patients and found that isolated ribosomes were synthesized and are in increased amounts of collagen. lonasescu, $\mathrm{V}$. et. al. [36] have also found similar situations in the carriers of DMD patients. Ribosomes were found to synthesize abnormally higher amounts of noncollagenous protein as well as collagen. Roses, A. D. et. al. [37] have studied and concluded that the increased ability of the erythrocyte membrane to phosphorylate protein is found in carriers of the illness. The mean values for groups of definite, probable and possible carriers were found to be similar and different from the mean value for matched healthy controls. The mutation rate must be very low. If there were non-carrier mothers in the possible and probable groups, their normal values of protein Kinase should have reduced the mean value of these two groups compared to the definite carriers.

Hobbins, J. C. et. al. [38] have studied an interesting concept of the detection of DMD patients. They have performed amneucontesis at the fifteen weeks of pregnancy and a determination of the sex of the fetus. If the fetus is female, the child will not suffer the clinical symptoms of DMD. If the fetus of the examination uterus is male, then mother may elect to have the pregnancy terminated. It is the question of emotional aspects of the mother and can be left to decide what should be done? Analysis of amniotic 
Sanjeev Kumar, Reena, Mittal, Sweety and D. C. Jain; Role of Trace Elements in Duchenne Muscular Dystrophy, Journal of Biomedical Engineering and Medical Imaging, Volume 1, No 5, Oct (2014) , pp 71-112

fluid CPK is not a useful test to detect whether a male fetus has the illness or not. It has become feasible to obtain fetal blood at the eighteen weeks during fetuscopy prenatal diagnosis of the illness.

Bodensteiner, J. B. et. al. [39] have studied calcium in muscle of DMD patients and found that there is a tendency of calcium level to be on the higher side. Bertorini, T. E. et. al. [40] have studied calcium and magnesium content in muscle of DMD patients and found that the levels of calcium were higher and levels of magnesium were lower. Some of the researchers have applied Freeze fracture technique (FFT) to study the muscle membrane and splits the surface membrane, peeling the outer surface away from the inner surface along a line, which passes through the interior of the membrane. Both the faces can be looked at under the electron microscope and these faces are found to be covered with particles of various types, some of which are arranged with a rectangular distribution. These are called square or orthogonal arrays.

Schotland, D. L. et. al. [41and 42] applied FFT to the DMD patients and found that there is a significant diminution in the number of orthogonal arrays. Peluchetti, D. et. al. [43] have studied this technique and suggested that there may be a decrease in the intermembranous particles on both surfaces.

The cell surface membrane is not homogenous. There are so many proteins and other compounds embedded in cell membrane, which serving different aspects of membrane activity. The glycoproteins and glycolipids of cell membranes perform important functions including a role in the receptor sites. There are some probes to identify these constituents by virtue of the selective binding of the probe to a specific compound. One such probe is Concanavalin A. This probe is a member of group of plant proteins called lections which have a specific affinity for sugar residues. Concanavalin A binds specifically with mannose, glucose, and fructose residues. Heimann-Patterson, T. D. et. al. [44] have studied the pattern of Concanavalin A binding in DMD patients and found that it was patchy and irregular. It was regular and have a good pattern in normal muscle. They have also found an abnormality in the cell membrane.

Brooke, M. H. [45] has written in his book on muscular dystrophy as if DMD is a primary abnormality in the muscle, then we would suppose to the change might be reproduced by culturing muscles cells from patients with the illness. Ionasescu, V.et.al.[46] and Thompson, E. Jet.al.[47] have studied DMD patients and found some abnormalities in the growth pattern which are able to change in the isoenzyme pattern of $\mathrm{CK}$ in the myotubes. It has also been noticed that this growth pattern is suspiciously normal in the cultured muscle. FFt does not reveal any abnormality in the inter membranous particles.

Rottman, S. M. et. al. [48] and Mawatri, S. et. al. [49] have found that the cultured cells seem to behave normally electro-physiologically. Cerri, C.A. et. al. [50] have found that there is abnormality in adenyl cyelase. It was not the same as that found in the dystrophic muscle itself.

It is believed that the possibility of hypothetical membrane abnormality might affect other tissues then muscle alone has been raised. DMD is a genetic disease and different cell surface membranes share many similar properties. Rowland, L. P. [51] has studied the relatively in exhaustible supply of membrane in the red blood cell and this has led to a legion of studies.

Falk, R. S.et.al.[52], Fischer, S. et.al.[53], Roses, A. D et.al.[54], Mabry, M. E. et.al.[55]and Roses, A. D. et.al[56] have studied the red cell membranes have been both inculpated and exculpated of all of the following such as changes in size, shape, deformability and other physical properties, abnormalities in 
different ATPases, changes in Calcium transport, abnormalities of electrolyte content and permeability, abnormal phospnorylation of protein, abnormalities of adenyl cyelase.

Arthur, H. et. al. [57] have found that there is an abnormality in low density lipoproteins in the plasma in DMD children leading to a suggestion that there transport capacity was impaired. Fibroblasts cultured from the skin of patients with the illness have also been harvested in an attempt to detect abnormalities. A decreased adhesiveness between fibroblasts has been described using a technique in which the cells are encouraged to collide with each other and the stickiness is measured in such collisions. The adhesiveness has been found to be reduced in the fibroblasts from Duchenne patients. There is an overlap between the normal healthy controls and the DMD patients. Cultured skin fibroblasts also contain $\mathrm{CK}$, which might make this a useful tool for studying the enzyme in disease states.

Minerals are important to our health. These are inorganic, chemical is elements not attached with carbon atom. Minerals and trace minerals can be differentiated easily. These trace minerals are called trace elements. If the cellular body requires less than $100 \mathrm{mg}$ of eleven minerals is labeled a trace element and if accepts more than this level is labeled a mineral.

Trace elements are required in quantities of few milligrams or micrograms per day. A study of relationships of minerals with human health is very necessary and important. A balance of the level for minerals in every organ, tissue and cell of the human body may lead to a good health.

Minerals comprise only a fraction of total body weight. These are crucial for many functions of the human body. These include transporting oxygen, normalizing the central nervous system (CNS) and simulating growth, maintenance and repair of tissues and bones [58].

Romeyn, M.[59] has given a statement that the regulation of trace elements balance in the body is essential to survival. Every cell is a living organism and we must try to maintain its internal environment. The mobility of trace elements across cell membranes, between the extra-cellular and intra-cellular fluid forms the basis for the body's most primary functions. The electrical activity may be initiated; heart beats, nerve cells signal, muscles may respond, blood vessels may tighten or relax. Water balance should be maintained.

Most of the trace elements found in the tissues and body fluids are also present in the blood. Some of the metallic elements have a specific metabolic function and the presence of these is not merely the result of contamination from our environment. The trace elements, which are biologically active produce their effects through enzyme systems. Metalloenzymes and metal protein complexes are two systems. The former has a fixed amount of specific metallic ion per molecule of protein addition of an agent, which binds the metal inactivates the enzymes and the later is a larger group of proteins loosely bound to metal. The metals may substitute for each other with fluctuating degrees of affinity and can be taken out from the body by the process of dialysis. Some of these complexes may have enzymatic activity only. Rests of these are concerned with transportation process only. Herring,W.B.et.al. [60] have shown that chelation affects the activity of enzymes . Khurshid, S.J.et.al.[61] and Suhaila,R. et.al.[62] have shown that the essential metals at trace levels play a role in the human body and can cause some diseases when present beyond the limit of normal concentration . 
Sanjeev Kumar, Reena, Mittal, Sweety and D. C. Jain; Role of Trace Elements in Duchenne Muscular Dystrophy, Journal of Biomedical Engineering and Medical Imaging, Volume 1, No 5, Oct (2014) , pp 71-112

It has been seen that the trace elements occur in the tissue of animals, plants and micro-organisms in very low concentrations. The concentration of these elements change highly among many elements. Their concentrations are also different among various living organisms and their parts. These differences are seen in nutritionally essential elements and also in those elements, which are associated with no vital function.

The trace elements have divergent roles to play depending upon their chemical form or combination and their position in the body fluids and tissues. The functional forms of the trace elements and their characteristic concentrations ought to be maintained with narrow limits if the functional and structural integrity of the tissues is to be safeguard and the growth, health and fertility of the individual have to be unaffected. Continued ingestion of diets that are deficient, imbalanced, or excessively high in a particular trace element invariably induces changes in the functioning forms activities, or amount of these elements in the tissue or fluids, so that they fall below, or rise above the normal and permissible limits or ranges. Biochemical disturbances in these situations develop along with physiological functions, which are influenced and structural disorders may arise due to the change with elements. Kumar, S.[63] has reported in his Ph. D thesis that the degree and duration of the dietary deficiency or toxicity, age, sex and species are important factors associated with the trace elements .

It has been seen that food is the basic need of life of a living organism. Everybody eats food whether it is vegetarian or non-vegetarian. Scientists were very curious about the food they consumed. Food passes in the body and affects the body. Food is the substance taken into the body that will help to meet the body's need for energy. It helps in maintaining good health, health growth, growth and reproduction.

Proteins are important and vital to any living creature. These are the important constituents of cells and tissues of the human body. Proteins form the important component of muscles and other tissues and vital body fluids like blood, cerebrospinal fluid (CSF) and synovial fluid in human joints. The proteins in the form of enzymes and hormones are concerned with a wide range of vital metabolic mechanisms in the body. They supply the body building material and make good the loss which occurs due to wear and tear. Proteins as antibodies may help the body to defend against infections. Proteins are one of the most important nutrients required by the body has to be supplied through the diet we consume. The dietary proteins are broken down into amino acids and absorbed and are used by the body for various functions like tissues building, replacement of proteins depleted, etc. Amino acids are used for providing energy to the body.

Fat is an important component of our diet. It serves a number of functions in the body. Fat is a concentrated source of energy and it supplies, per unit weight more than twice of energy furnished by either proteins or carbohydrates. Fat also imparts palatability to a diet and retards stomach emptying time. Fat in the diet can be of two categories, the visible and invisible. The visible fats are those derived from animal fats like butter, ghee which are solid fats and those derived from vegetable fats like groundnut, mustard, coconut, sunflower oil, till, which are liquid fats. Hydrogenated vegetable oil known as Vanaspati is a solid fat. These fats are triglyceride of fatty acids, both saturated and unsaturated. Animal fats like ghee and butter contain Vitamin A and D. These vitamins are not present in vegetable oils. 
Some amount of fat is present in other foods like cereals, pulses, oil seeds, milk, egg, meat, etc. This type of fat contributes to the total fat and essential fatty acids content of diet depending upon the foodstuff present in the diet. Nuts, oilseeds, soyabean, avocado, pear and animal foods have a higher amount of invisible fat.

Minerals and trace elements are circulating in the human body. Some of these elements form part of body structural component and some others act as catalytic agents in different body reactions. Bones and skeleton are made up of calcium, magnesium and phosphorus and iron, which is a component of blood. Minerals like zinc, molybdenum, copper, manganese and magnesium are either a structural part or activate a large number of enzyme systems. lodine is a part of hormone, thyroxin. Sodium, potassium are important elements present in fluids within the outside the cells and along with ions like chloride, bicarbonate and carbonate keep water and acid base balance.

Every individual absorbs minerals in a slightly different way, called biochemical individuality. Those nutrients that have not been transferred through the intestinal mucosal cell to enter the circulation have no meaning regarding the study of the elements. The variety of nutrients from organism's environment that have been made available by absorption must be transported through the circulatory system to the aqueous microenvironment of the cells. They may serve the purpose of participation in different metabolic processes in the cells on which the life of the total organism depends.

The absorption of minerals is dependent on many different factors related to the mechanism of human body. Mary, R.L.A. et.al [64] have reported that the addition of vitamins and minerals to food can be effective public health intervention to correct inadequate intake of nutrients in both the general society.

\subsection{Different types of Trace Elements circulating in Human system:}

There are ninety two elements found in nature. We have some additional twenty two elements also. It has been reported in the literature that there are hundreds of isotopes of the elements exist. We may say the any one of which may play an undiscovered role in human health.

Alaxander,G.S. [65] reported that through geophysical forces, mixing of the earth's crust with water may provide virtually every mineral for our body, which requires to maintain health. The water is compatable with more substances that any known solvent. It is an ideal medium for transporting nutrients in the cells for the chemical reactions of cellular metabolism to take place. Human body contains lot of element out of 25 are divided into mainly three categories such as major, minor components and trace elements.

Pike, R.L.et.al.[66] have given a statement that the major components, which make up $96 \%$ of human body are composed of oxygen, nitrogen, carbon and hydrogen. Major elements found in the biological molecules such as proteins, nucleic acids, fats and carbohydrates and are capable to make-up the body. Hydrogen ions are very important for our cells to make ATP or energy. Water is also a medium for all the chemical reactions taken place in the human body. Water is a mixture of oxygen and hydrogen atoms .

Minor components make up $4 \%$ of our body. They may include calcium, phosphorus, potassium, sulfur, sodium, chlorine and magnesium. Some of these are necessary for chemical processes to run correctly. Our muscles need calcium in order for them to twitch properly. Enough calcium is required to our body. 
Sanjeev Kumar, Reena, Mittal, Sweety and D. C. Jain; Role of Trace Elements in Duchenne Muscular Dystrophy, Journal of Biomedical Engineering and Medical Imaging, Volume 1, No 5, Oct (2014) , pp 71-112

Trace elements make up $0.1 \%$ of our body. They include copper, zinc, selenium, molybdenum, fluorine, iodine, manganese, cobalt, iron, lithium, strontium, aluminum, silicon, lead, vanadium, arsenic and bromine. These elements are essential for our body to function properly.

Zumkley, H. [67] stated that clinical experimental and epidemiological studies indicate that a large number of trace elements may be involved in the etiology of different human body disorders. Both increased levels of any trace element or reverse of this can influence the development of disease.

\section{Trace Elemental Effects on Human Health}

A very high concentration of the trace elements may prove toxic. Depletion in the concentration of essential trace elements may lead to create so many different metabolic instabilities due to dysfunction of enzyme. Different types of metabolic changes in human body are accompanied by changes made in the concentration of one or more trace elements in some body fluids, such as blood serum or plasma.

The trace elemental analysis from human hair, nails, and body fluids such as plasma, serum and cerebrospinal fluid has been stated in the literature as the best predicator.

\subsection{Trace elemental role in human Body:}

We are giving the description of some of the important trace elements here as

\subsubsection{Copper:}

The presence of copper in animals and plants is very necessary. Copper is most abundant trace element in human beings. This element is carried mostly in the bloodstream on a plasma protein. We may call it is ceruloplasmin. This element is firstly absorbed in the gut and transported to the liver bound to albumin. It is found in a variety of enzymes, including the copper centre of cytochrome $\mathrm{C}$ oxidase.

Human body needs copper for normal growth and health. It is said that copper is required to help body use iron. This element is very important for nerve function, bone growth and to help body use sugar and it is a component of a cofactor for different enzymes, approximately. Fifty enzymes are required copper to function properly. Davis, I.J.J. [68] has given a statement that a young person requires one hundred to one hundred fifty milligram of copper daily. Copper in higher concentration is found in liver, hair, muscle and lung.

\subsubsection{Zinc:}

Zinc $\mathrm{Zn}$ ) is a necessary trace metal of suitable importance in the dietary management of many human body complex disorders. A young person has $3 \mathrm{gm}$ of zinc. This trace element is found in all our cells. This element is essential for all forms of life. Many proteins contain structures called zinc fingers may help to regulate genes. The distribution of zinc in human tissues is well documented in the literature. Liver, kidney, bone, retina, prostate and muscle appear to be very rich in zinc. Burns, R.R. et.al.[69] have studied and found that most of the red cells zinc is tightly bound to enzyme carbonic anhydrase. It is exchangeable with plasma zinc. Whole of plasma zinc is found with proteins. Sixty percent zinc is bound to albumin and thirty percent has binding with alpha 2 macroglobulin and the remainder with low molecular weight proteins including amino acids.

Prasad, A. S. et. al. [70] have shown that zinc is bound to amino acids and serum proteins. Histidine, glutamine, threonine, cystine and lysine showed the most markable effects. The amino-acid-bound 
fraction of zinc may have an important role in biological transport of zinc. The stable zinc content is higher in albumin fraction. Similar concentrations of zinc were found in the $\alpha, \beta$ and $\gamma$-globulins. These are fraction of immunoglobulin G.

Kelin, D. et. al. [71] have shown the first demonstration of a specific biological function critically dependent on the presence of zinc. They have also shown that carbonic anhydrase contains zinc and it is essential to the mechanism of action.

Riordan, J. F. et. al. [72] have reported in the literature that there are more than seventy zinc metalloenzymes. Zinc metalloenzymes exhibit diversity both of catalytic function and of the role played by the metal atom.

It is evident that zinc in small quantities is present in various cell membranes. Most of the membranebound zinc is linked to a distinct macromolecule constituent lipoprotein fraction. Chavapil, M.et.al.[73] have shown that the effect of zinc and other metals on aggregation of platelets and release of $\mathrm{H}^{3}$ serotonin activated either by collagen or epinephrine .

Prasad, A. S. et. al. [74] have shown that a syndrome of iron deficiency anaemia, hepatosplenomegaly and dwarfism has been found to be associated with malfunctioning of zinc metabolism . Walravens, P.A. et.al.[75] have studied and found that the orthopedic and CNS have relatively slow zinc uptake. This element remains tightly attached for a lengthy span of time. The deficiency of zinc leads to growth retardation or failure, lesions of the skin and its appendages, and impaired reproductive development and function. Psychological disturbances are reported in individuals suffering from acrodermatitis enteropathic . Henkin, R.I. et.al.[76] have studied zinc induced deficiencies in human beings and these are associated with neurological symptoms such as depression, poor concentration, nervousness and moodiness . Dresti, I.E. [77] has studied the hippocampus, which is rich in zinc. Zinc deficiency is associated with learning and memory defects similar to behaviour syndromes resulting from destruction of the hippocampus. Acute oral zinc toxicity has been reported to produce drowsiness and somnolence.

\subsubsection{Iron:}

Fairbanks, V. E. F. et. al. [78] have reported that the therapeutic indications for iron during the Roman era included alopecia, acne, dermatitis, wounds, hemorrhoids, gout, pulmonary diseases, diarrhoea, vomiting, weakness, edema, fever and cystitis. McCance, et. al. [79] have reported that once the iron was absorbed by the human body, its excretion was very minimal and was not controlled either by gastrointestinal tract or by the kidneys. The plasma iron was in equilibrium with tissue iron. The level of plasma iron influenced the rate of iron absorption. The intestine regulates the rate of iron absorption.

Granick, S. [80 adopted and extended the hypothesis of ferritin as the mucosal regulator of iron absorption. This hypothesis was used and named as mucosal block theory. Moore, C. V. et. al. [81 have shown that the plasma iron as the major form of transport iron. Flavoprotein enzymes of iron were discovered by Mahler, H. R. et. al. [82] and Richert, D. A. et. al. [83]. Fisher, H.et.al. [84] have synthesized four ferroprotoporphyrin (heme) moieties.

Ingram, D. J. E. et. al. [85] have extablished a three-dimensional picture of molecule with its four attached hemes. They have studied the nature of the bond between iron and globin. Now iron is 
Sanjeev Kumar, Reena, Mittal, Sweety and D. C. Jain; Role of Trace Elements in Duchenne Muscular Dystrophy, Journal of Biomedical Engineering and Medical Imaging, Volume 1, No 5, Oct (2014) , pp 71-112

stabilized in the ferrous state completely, which allows it to be reversibly bonded to oxygen. Due to this mechanism, hemoglobin works as an oxygen carrier.

The iron in human serum was studied by Holmberg, G. C. et. al. [88] Schade, et. al. [87] have shown that the trace element iron may be bounded completely to transferrin.

Lipschitz, D.A. et.al.[88] and Simes, M.A.et.al.[89] have established a correlation between serum ferritin, concentration and storage iron.

\subsubsection{Magnesium:}

Aikawa, J. K. [90 and 91] showed in the studies related to magnesium and found that magnesium is associated with so many different biological processes.

Magnesium is present in a small concentration in all cells and it is necessary for cellular metabolism. This trace element is also present in bone along with calcium. It shares so many properties of calcium so far as absorption and metabolism and tissue distribution are concerned. Widdowson, E. M. et. al. [92] have studied the magnesium content in human body and found a range of magnesium, which stated from 22.7 to $35.0 \mathrm{meq} / \mathrm{kg}$ weight of tissues. Magnesium reaches us in many forms. These are magnesium amino acid chelate, magnesium carbonate, magnesium oxide, magnesium oxide dolomite and magnesium sulfate. Seventy percent of human body magnesium resides in bones and teeth.This element is essential to the functioning of human body because it transmits nerve impulses, causes contraction of muscles and integral to healthy development of bones and teeth. Waterlow, J.C.[93], Clasen,H.G.[94] and AL-Ghamadi,S.M. et.al.[95] have shown that the human body contains about 760mg of magnesium at the time of birth. It goes upto $5 \mathrm{gm}$ at the age of 4-5months and it reaches upto $25 \mathrm{~g}$ when a body attains an age of adult. About 30 to $40 \%$ magnesium is found in muscles and soft tissues. One percent is found in extracellular fluid, and the remainder is in skeleton. If we are going to consider the particular importance with respect to the pathological effects of magnesium depletion. We have to take into account the role of this element in regulating potassium fluxes and its involvement in the metabolism of calcium. Wester,P.[96] has shown that

about $1 \%$ of magnesium is found in the extracellular fluid, inside cells, magnesium may be bound to phospholipids. It is very important to note that increasing dietary protein intake may increase magnesium requirements because high protein intake may decline magnesium retention .It is advisable that to completely understand magnesium function, it is very important to explore magnesium's relationship with calcium and potassium. Magnesium and potassium also have a close relationship. Magnesium is required for the function of sodium and potassium pump. If a magnesium deficiency occurs, then pumping of sodium out of the cell and pumping potassium into the cell may be impaired. Krasner,B.[97] ,Furukawa,Y.et.al.[98],Stark,G. et.al.[99] and Haigney,M.C.P. et.al.[100] have studied and shown an effect of the level of magnesium regarding heart attack.

Alcoholism, renal disease, diabetes mellitus may all cause a deficiency of magnesium. Nausea, vomiting, anorexia, muscle weakness, muscle weakness, muscle spasms and tremors are the few symptoms and signs related to deficiency of magnesium.

Magnesium has an effect on CNS. It is used for a better sleep. This element may be used to calm irritated and over excited nerves. This is useful with epileptic attacks, convulsions in pregnant women 
and shakes with tremors in alocholism. If the level of magnesium is very low, the nerves lose control over muscle activity, respiration and mental processes. Nervous fatigue, ties and twitches, tremors, irritability, hypersensitivity, muscle spasms, restlessness, anxiety, confusion, disorientation and irregular heartbeat all respond to higher levels of magnesium.

\subsubsection{Calcium:}

We know that $99 \%$ of calcium is found in the bones and teeth of a human body. Rest of the element resides in the soft tissues and blood of the body. Calcium is most important element of the body and human body structure is made up calcium and other minerals. We shall lie on the ground without calcium and not able to stand.

Ireland,P.et.al.[101]. Heaney,R.P.et.al.[102] ,Wilkinson,R.et.al.[103] and Marshall,D.H.et.al.[104]have studied the ingested calcium mixes with digestive juice calcium in the proximal small intestine from where it is absorbed by a mechanism. This process has an active saturable component and diffusion component .Calcium is absorbed by active transport during the low calcium intake mainly. This active transport is called trans cellular transport. High intake of calcium lead to increasing proportion of calcium, which may be absorbed by paracellular diffusion. The unabsorbed component appears in the faeces together with the unabsorbed component of digestive juice calcium. This is called as endogeneous faecal calcium. The faeces contain unabsorbed dietary calcium and un reabsorbed digestive juice calcium. Urinary and endogenous faecal calcium are not the only forms of calcium for excretion. The calcium looses from skin, hair, nails must taken into account. The deficiency of calcium causes osteoporosis. Morris ,H. et.al.[105] ,Ebeling, P.R.et.al.[106] , Need,A.G. et.al.[107] have shown that the calcium absorption decreases with the increase of age in both males and females .

Nordin, B.E.C.et.al.[108] shown that the calcium content of human milk is $36 \mathrm{mg}$ per $100 \mathrm{ml}$. A lactating lady may produce $750 \mathrm{ml}$ of milk daily. It has been reported that $280 \mathrm{mg}$ of calcium can be fed to a new born child. Kent, G.N. et.al.[109] and Lopez, J.M. et.al. [110] have shown that the bone is lost during lactation and restored after weaning. Chan. G.M.et.al. [111] have shown that the loss of calcium may be prevented by the supplementation of calcium. Calcium deficiency is very serious. Researchers have shown a low bone density. Due to low density, the fracture rate is very high in developing countries. The intake of calcium is also low. Rickets has not been reported in developing countries.

\subsubsection{Sodium:}

Sodium was isolated in the year 1807 by passing an electric current through molten sodium hydroxide. The sodium quickly oxidizes in air and is reactive. The free metal is used for chemical synthesis, analysis and heat transfer applications. Sodium ion is soluble in water. Most of the sodium in the human body is found in blood and lymph fluid. Aldosterone hormone controlled partly the levels of sodium in human system. Adrenal glands are responsible for the hormone. The level of aldosterone in human body tells about the kidneys when to hold the sodium element in the body instead of passing it in urine. Small amounts of sodium may last through the skin during the process of sweating. The ability of the kidney to both conserve sodium in response to sodium deprivation and to excrete sodium in response to sodium loading are impaired with the aging factor. Blood pressure in the body has to be maintained at the 
Sanjeev Kumar, Reena, Mittal, Sweety and D. C. Jain; Role of Trace Elements in Duchenne Muscular Dystrophy, Journal of Biomedical Engineering and Medical Imaging, Volume 1, No 5, Oct (2014) , pp 71-112

prescribed and standard rates. If the standards of the pressure are failed, the system leads to serious damage of the blood vessels and results might be lethal.

\subsubsection{Potassium:}

This element is very important for the proper function of all cells, tissues and organs in the human system. This is an electrolyte able to conduct electricity in the body, along with sodium, chloride, calcium and magnesium. It is very crucial element to proper heart function and plays an important role in skeletal and smooth muscle contraction, making it very useful for normal digestive and muscular function. This element acts as a conductor for energy impulses throughout the body. It triggers chemical reactions in the body.

Potassium ion diffusion is a key mechanism in nerve transmission, and potassium depletion in human. There are some neurological dysfunctions such as epilepsy, headache, migraine, muscular dystrophy and Alzheimer's disease developed by the fluctuations in levels of potassium in the blood.

\subsubsection{Hyperkalemia:}

If we found the levels of potassium in the blood higher than normal value then a disease may occur, which is called hyperkalemia. This may be related to an increase in total body potassium or the excess release of potassium from the cells into the blood stream. Kidneys remove excees potassium from the body. It has been found in most of the cases that hyperkalemia is caused by disorders which reduce the ability to get rid of potassium. These disorders are such as acute kidney failure, chronic kidney failure, glomerulonephritis, obstructive uropathy and rejection of a kidney transplant.

\subsubsection{Hypokalemia:}

Hypokalemia means serum or plasma levels of potassium below the normal value. There are two causes for hypokalemia defined here, one is related to overall depletion in body's potassium and the next is related to excessive uptake of potassium by the muscle from the surrounding fluids. It is well reported in the literature that need have potassium is to control muscle action. Hypokalemia can cause the heart to stop breathing.

Mild hypokalemia does not show any symptom understandable position is missing. If a person has moderate hypokalemia which is very important to diagnose easily by the help of some understandable symptoms such as confusion, disorientation, weakness and discomfort of muscles, discomfort in the legs. Severe hypokalemia may produce extreme weakness of the body, paralysis. Different types of paralysis such as flaccid, limpness, lung muscles are common. This type of hypokalemia may cause abnormal heart beat. Abnormal heart beat is dangerous for our heart and it is the sign of cardiac arrest. Hypokalemia does not show any symptom in healthy subjects because of the rich percentage of potassium is found in healthy persons.

\subsection{Trace elemental role in relation to immunity:}

Nutrition and health both are linked each other but the importance of trace elements on immune system is also a field of research, which was established in the last two decades. It is a field of understanding of adequate trace elements supplementation may be a good path to design a better nutrition, which protects human beings against infections. 
Cell biology and molecular genetics are the branches of science have been facilitated main efforts to determine specific cellular and molecular functions of trace elements in maturation, activation and functions of host defense mechanisms.

Immune cells require a proper supply of trace metals to express and preserve the structure and function metalloproteinase. These cells may also participate in energy production. Trace element levels can affect the immune function not only in a direct process but also by modulating plasma levels of hormones which are used to regulate the development and function of host deference cells. The trace elements may influence some mechanisms of non-specific immunity by modulating inflammatory cell function.

It has been seen that the effect of mineral deficiency on acquired immune system can be demonstrated by examining the response of lymphocytes to T cells mitogens. The levels of trace elements may also affects the synthesis and secretion of cytokines and chemokines which modulate the activities of immune and other cells.

A good application of micronutrient which is also called as trace elements interventions is probably related to vaccine response in older stage in human beings. Mortality associated with influenza is more likely to appear in this population.

A significant physiological role of many trace elements in the development, maturation, and sustenance of the morphologic integrity and function of the lymphoid organs concerned with immunity has been well established.

The immune system plays a key role in the body's ability to fight against infections and reduce the risk of developing tumors autoimmune and degenerative disease. Nutritional deficiencies and excesses influence different components of the immune system.

\section{Review of the Literature}

Katz, M. [112] and Suskind, R. M. [113] have studied the influence of nutrition upon host immune compertence. Correlations of protein and energy nutriture and their role in immuno responsiveness have been studied by- Bongiorni, I. B. et. al. [114] and Malave, I. et. al. [115]. Many trace elements are critical for mammalian survival and reproduction. High consumption of highly refined and heavily processed food items reflect that the trace element content may be reduced significantly. Gershwin, M.et.al.[116] have shown that the value of level of zinc may affect the phagocytic cell function the complement system and mast cell mediator release which can be seen at the efferent arm of immune response .

Rigas, et. al. [117] have reported that an additional process due to which copper acts in altering immune response may involve an interaction at the level of the plasma membrance.

Calcium ion are involved intimately is so many aspects of lymphocyte activation such as blast transformation in response to mitogens. Calcium is known to complete in a number of biological systems. Walton, W. S. et. al. [118] have suggested regarding elements metabolism and body composition and found that life in its very early stage surely included the conjunction of mineral ions with the simplest organic compounds and with subsequent nucleic acids and proteins to determine the 
Sanjeev Kumar, Reena, Mittal, Sweety and D. C. Jain; Role of Trace Elements in Duchenne Muscular Dystrophy, Journal of Biomedical Engineering and Medical Imaging, Volume 1, No 5, Oct (2014) , pp 71-112

form and function of cellular components and processes. A separation of many cations and anions accompanied the creation of membranes and the development of the cell. Electro chemical and electromotive forces were already established with selective, often linked, passage of organic and inorganic molecules through channels or pores in membranes. A bioenergetics system developed and the fundamental, unique nature of intracellular life was also determined. Disturbances or breakdowns in the dynamic system development on location, movement and functions of mineral ions underlie many diseases of CNS and other different types of diseases.

Malcolm, J. J. et. al. [119] have measured calcium and other elements in muscle biopsy samples from patients of Duchenne muscular dystrophy (DMD) and found that the calcium content of muscle of DMD patients was significantly elevated compared to normal healthy controls.

Allen, D. G. et. al. [120] have studied calcium and the damage pathways in muscular dystrophy and found that the stretched contractions activate ROS production, which activates src kinase. Activity of such type of kinase causes opening of SACNSC and allows $\mathrm{Ca}^{++}$entry. This pathway may be a possible cause of muscle damage.

Imbert, N. et. al. [121] have studied abnormal calcium homeostasis in DMD myotubes contracting in vitro and found that the resting intracellular calcium level was significantly higher in contracting DMD cells and it was (107 $\pm 8 \mathrm{n} \mathrm{M})$. The level of calcium in controls was (66 $\pm 6 n \mathrm{M})$. It was $(56 \pm 6 n \mathrm{M})$ in FSM cells. They have also reported that contraction is a dominant factor contributing to $\mathrm{Ca}^{++}$ abnormalities in DMD cells. Contracting dystrophin-deficient cells have defective calcium handling mechanics during electrical events which involve sarcolemma.

Rena, Y. et. al. [122] have studied elements in muscle measured in vivo and vitro with X-ray spectrometry. They have found that muscles of myopathic animals had pathologic changes. The tongue and myocardium are composed of red fibers showed excessive calcium accumulation. This suggest that the basic genetic aberration is not directly related to the oxidative metabolism, white muscles have a more efficient system for dealing with calcium overload.

Caroline, A. M. et. al. [123] have studied elemental analysis of skeletal muscle in DMD using X-ray fluorescence spectrometry. They have found that levels of calcium and copper were significantly elevated in DMD compared to controls. X-ray fluorescence spectrometries provide further evidence for the involvement of calcium in dystrophic processes.

Hisao, K. et. al. [124] have studied Manganese, Copper, Zinc and Iron concentrations and subcellulor distribution in two types of skeletal muscle and found that the iron, zinc, copper and manganese concentrations of red muscle were 1.83, 4.31, 2.05 and 1.67 times higher than those of white muscle respectively. They have also reported that in skeletal muscle subcellulor distribution of iron, zinc and copper were different. The distribution of manganese does not have any deviation from the liver. They have also suggested that the differences between subsarcolemmal and interfibrillar mitrochondria were ascertained by the distribution of the trace elements.

Turner, P. R. et. al. [125] have studied increased calcium influx in dystrophic muscle and found that increased calcium influx or decreased efflux could lead to elevated $\left[\mathrm{Ca}^{++}\right]_{i}$ levels. The calcium sequestering mechanisms were not altered in dystrophic muscle but were slowed by higher resting. They have also suggested that the agents increased leak channel activity due to this activity there is also 
increment of $\left[\mathrm{Ca}^{++}\right]_{i}$ in fibers and myotubes. The increased calcium influx could result in elevated $\left[\mathrm{Ca}^{++}\right]_{\mathrm{i}}$ in dystrophic muscle.

Arthur, J. R. et. al. [126] have studied free radicals and trace elements in muscle disorders and sport. They have suggested that trace elements and free radical activity can be associated with the pathogenesis of some skeletal and cardiac myopathies. They have also concluded that the deficiency of vitamin $\mathrm{E}$ may be a causative factor of the disease.

Baharch, M. et. al. [127] have studied nutritional inadequacy in adults with muscular dystrophy. They have reported that patients with DMD may be prone to nutrient deficiency due to mobility limitations or orophayngeal weakness. Patients with myotonic muscular dystrophy may be prone to nutritional deficiencies from associated dysmotility of the entire gastrointestinal tract. Many patients in both groups of dystrophies demonstrated in adequate nutrient intake of protein, energy, vitamins, water, fat, calcium and magnesium. They have also spot out the current dietary intake recommendations could not be properly maintained in adults of DMD.

Kando, H. et. al. [128] have studied trace element movement and oxidative stress in skeletal muscle atrophied by immobilization. They have measured $\mathrm{Fe}, \mathrm{Zn}, \mathrm{Mn}$ and $\mathrm{Cu}$ concentrations and the levels of thiobarbituric acid-reactive substance and glutathione. The rate of atrophy increased rapidly. Fe concentration has a tendency of elevation. Zinc and Manganese were also elevated. Their sub cellular distributions were also changed.

Gage, V. H. et. al. [129] have studied hypokalemic myopathy and elevation of serum enzymes. They have found and observed that there was an alteration in serum enzymes specially CPK. Altered potassium metabolism has already been associated with muscle dysfunction. There is a link between hypokalemia, myopathy and serum enzyme elevation, which has already reviewed and lot of literature available to have a better attainment regarding the disease.

Howard, M. K. et. al. [130] have studied malignant hyperthermia in a child with DMD. They have reported that patients with DMD are susceptible to different adverse intraoperative and postoperative side effects of anesthetic agents. These include hyperthermia and hyperkalemia, systemic acidosis, cordiac abnormalities rhabdomyolysis as well as death. They have concluded that response to testing of a muscle biopsy specimen was consistent with the diagnosis of malignant hyperthermia.

William, B. et. al. [131] have studied body potassium content in patients with muscular dystrophy. The significance of potassium metabolism in muscle disease has been the subject of investigation and speculation for the last about more than fifty years. The essential nature of potassium in the synthesis of muscle protein is well established. Potassium has also been implicated in the physiochemical interaction associated with muscle contraction, Role of potassium and determination of this element is very necessary in the diseases of muscle.

Serum potassium levels in primary muscle disease are consistently within the normalcy. Ninety five percent of the body potassium is intracellular. Serum values of potassium cannot reflect intracellular derangements of potassium metabolism. A method which can measure total body exchangeable potassium is isotope dilution that does not depend on serum potassium levels. 
Sanjeev Kumar, Reena, Mittal, Sweety and D. C. Jain; Role of Trace Elements in Duchenne Muscular Dystrophy, Journal of Biomedical Engineering and Medical Imaging, Volume 1, No 5, Oct (2014) , pp 71-112

Authors have studied potassium by means of radioactive method and found that patients with primary muscle disease have a diminution in total body potassium, which was correlated in large measure with the severity of muscle involvement. This study was done in the case of relatives of the patients and found a similar decrease in body potassium. Authors have also investigated that the relationship of body water with primary muscle disease. A consistent relationship between body potassium and a fundamental component of body composition has been established.

Kossmann, R. J. et. al. [132] have studied neuromuscular diseases. They have given their views on the importance of potassium in biological functions. Potassium plays a role of protein synthesis in muscle. It plays a role in creatine phosphorylation, which is necessary to energy transfer. Potassium maintains the membrane potential too. Abnormalities of potassium distribution in the human body become manifest as muscle dysfunction in disease such as cardio renal failure, diabetic acidosis, and periodic paralysis. The disturbance in potassium has been also reported in the many neuromuscular diseases. Authors have tried method of natural radioactivity to study the whole body potassium up to the accuracy of $2 \%$ in less than two hundred seconds. Authors have determined the potassium in muscular dystrophy and found that significance of the measured values were uncertain. It is very hard to say that whether this is a fundamental pathogenesis or a consequence of loss of muscle in bulk.

Hull, K. L. et. al. [133] have studied stoichiometry of sodium and potassium transport in erythrocytes from patients with myotonic muscular dystrophy. They have used ${ }^{22} \mathrm{Na}$ and ${ }^{42} \mathrm{~K}$ radioisotopes to measure $\mathrm{Na}$ efflux and $\mathrm{K}$ efflux in identical suspensions of fresh erythrocytes from patients of myotonic dystrophy and controls. Each flux was measured in the presence and absence of ouabain. The mean ouabain-sensitive Na efflux rate in controls was found to be significantly greater than the corresponding rate in myotonic dystrophy.

Edmands C. J. et. al. [134] have studied total body potassium and water, and exchangeable sodium in muscular dystrophy. They have found that total body potassium was reduced even in the youngest patients and was slightly higher in the older boys. Total body water was also reduced. The total body water measurements indicated that many of the affected boys were obese.

William, H. B. et. al. [135] have studied the significance of decreased body potassium concentrations in patients with muscular dystrophy and non dystrophic relatives and found that diminished total body potassium concentrations appear to correlate with the severity of muscle involvement. They have also provided a logical explanation for the loss of body potassium level. It is related to the gradual replacement of normal muscle tissue by potassium poor fat.

Rowland, L. P. et. al. [136] have studied lack of some muscle proteins in serum of patients with Duchenne dystrophy. They have studied phosphofructokinase (PFK), phosphorylase (PPL) and myoglobin in normal human muscle diseases. The PFK and myoglobin were absent at all. The activities of PPL were very slow. The abnormal increase in the activity of several serum enzymes is one clue to the nature of the biochemical abnormality in the cases of DMD. The increased serum enzyme activity may occur because enzyme protein molecules are released from muscle. This is the fundamental disorder of an abnormality of the muscle membrane. This abnormality permits pathological leakage of large molecules.

Hopf, E. W. et. al. [137] have studied calcium misregulation and the pathogenesis of muscular dystrophy. The exact nature of the relationship between calcium and pathogenesis of DMD is still an 
open question. It is very difficult to understand the cellular basis of DMD. The absence or low level of dystrophin, a cytoskeleton protein may slow the necrosis of the muscle fibers with progression of the disease. Loss of cytoskeletal and sarcolemmal integrity results from the absence of dystrophin. It plays a role in the pathogenesis of DMD. A number of calcium-permeable channels have been identified, which can exhibit greater activity in dystrophic muscle cells.

Neve, J. [138] has studied quite different element selenium (Se) and put forward basic views regarding this element. Selenium has been appreciated in nutrition and therapeutics for the last three decades. Selenium constituting the active centre of about 20 eukaryotic proteins. It has been considered as highly relevant in Biochemistry. It can be used as radox state regulating properties. Besides well characterized selenium deficiency symptoms appear in pronounced deficiency states and are associated with different and various cofactors. The deficiency of this element causes significant adverse effects. It can increase the susceptibility of cancer, cardiovascular diseases or some other chronic degenerated pathologies such as DMD. Dietary recommendations of selenium not defined very much and are inadequate.

Westermarck, T. et. al. [139] have studied the trace element Se and reported the importance of this element as nutrition in protecting against so many degenerative and chronic neurological diseases. The nutritional antioxidants may be effective in preventing or retarding the process of the disease. It has been reported that a clinical response is also effective in the treatment of the DMD patients.

Alain, L. et. al. [140] have studied selenoprotein function in muscle disease. The crucial role of the trace element Se in livestock and human health in striated muscle function has been well established. There are two proteins discovered till date and these are Sel W and Sel M. Some of the recent findings on the functional consequence of the mutations suggest and an important contribution of Sel $M$ to the regulation of oxidative stress and calcium homeostasis.

Zunkley, H. [141] has studied the clinical aspects of selenium metabolism. Selenium deficiency has been recognized to play secondary role in different human diseases. Many of these diseases can be prevented or treated by means of selenium supplementation. Importances of selenium with other trace elements are also of clinical significance.

Harris, L. S. et. al [142] have studied magnesium and calcium in human muscular dystrophy. They have mentioned that new impetus has been given the study of distribution and utilization of metallic ions in DMD by increasing recognition of their influences upon activities of enzymes. There are so many abnormal activities of different types of glycogenolytic enzymes, transminase, nueleotidase and creative phosphokinase in DMD have very much studied earlier. They have also reported that all of the enzymes catalyze the transfer of phosphate from adenosine triphosphate (ATP) to a phosphate receptor, or from a phosphorylased compound to adenosine diphosphate (ADP) are activated by magnesium ATP is necessary in such diverse functions as muscle contraction.

Samuel, W. B. et. al. [143] have studied plasma and erythrocyte magnesium in muscular dystrophy. They have reported that magnesium in serum is tightly bound in dystrophic patients. It has different value in normal persons. Studies of magnesium metabolism in pseudo hypertrophic muscular dystrophy are appropriate. Magnesium works as a metal cofactor in many reactions of muscle metabolism. There is a necessity of optimum levels of magnesium in muscle fibers for contraction and relaxation of muscle. 
Sanjeev Kumar, Reena, Mittal, Sweety and D. C. Jain; Role of Trace Elements in Duchenne Muscular Dystrophy, Journal of Biomedical Engineering and Medical Imaging, Volume 1, No 5, Oct (2014) , pp 71-112

Tulio, E. B. et. al. [144] have studied muscle calcium and magnesium content in Duchenne muscular dystrophy. They have found that muscle calcium levels were fifty percent higher in comparison to normal healthy persons. The levels of magnesium were decreased by forty four percent in DMD persons in comparison to healthy controls. Authors have given their arguments for the role of calcium in DMD, which were very authentic and may implicate magnesium depletion as secondary pathogenic factor.

Csenkér, E. et. al. [145] have studied ion concentrations in serum and cerebrospinal fluid of patients with neuromuscular diseases. Authors have studied $\mathrm{Na}^{+}, \mathrm{Ca}^{+2}, \mathrm{~K}^{+}, \mathrm{Ce}^{-}, \mathrm{Mg}^{2+}$ and $\mathrm{Pi}$ concentrations in serum and lumber CSF with neuromuscular diseases. They have measured pi concentration, which was remarkable point of diagnosis in DMD. On the basis of ion content with possible alterations of serum of CSF may guide us in the diagnosis of various neuromuscular diseases.

Carlier, L. et. al. [146] have studied nutritional assessment in Duchenne muscular dystrophy. Authors confirmed the accuracy of the DMD ideal-weight chart of earlier scientists. Obesity may occur from the age of seven years. Obese boys show a centralized body-fat distribution. They have also concluded that a specific weight chart and simple clinical tools are sufficient to obtain on accurate diagnosis of nutrition or obesity among DMD patients

\section{Basic Theory of Flame Atomic Absorption Spectroscopy}

The phenomenon of atomic absorption was first observed in 1802. Walsh proposed the atomic absorption spectroscopy for the quantitative analysis of elements [147]. Skoog et. al. [148] have supplied relevant information about this technique in detail. Atomic absorption analysis involves measuring the absorption of light by vaporized ground state atoms and relating the absorption to concentration. The incident beam of light is attenuated by atomic vapor absorption according to Beer's Law. The instrumental and chemical parameters of the system must be geared towards the production of neutral ground state atoms of the proposed element for study. The conversion of sample from its native state to the atomic state can be achieved by using a method called flame atomic absorption spectroscopy (AAS) or an electric furnace. The sample undergoes a number of pretreatment steps prior to analysis in the furnace. The sample is dried by evaporating the solvent in the first step. The organic matrix is decomposed by heating the sample in the second step. The heating temperature may go up to $1000^{\circ} \mathrm{C}$. Ultimately the furnace is rapidly heated to a temperature around $2400^{\circ} \mathrm{C}$ to produce vaporized neutral atoms with as many as possible in their electronic ground states. Block diagram of a flame spectrophotometer is given in Figure 4. 1.

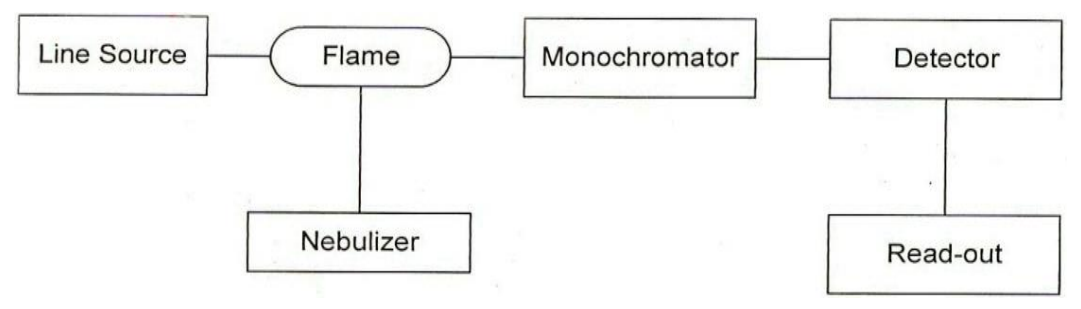

Fig. 4.1 : Block diagram of a flame spectrophotometer.

Optical arrangement of atomic absorption spectrophotometer is given in Figure 4. 2. 


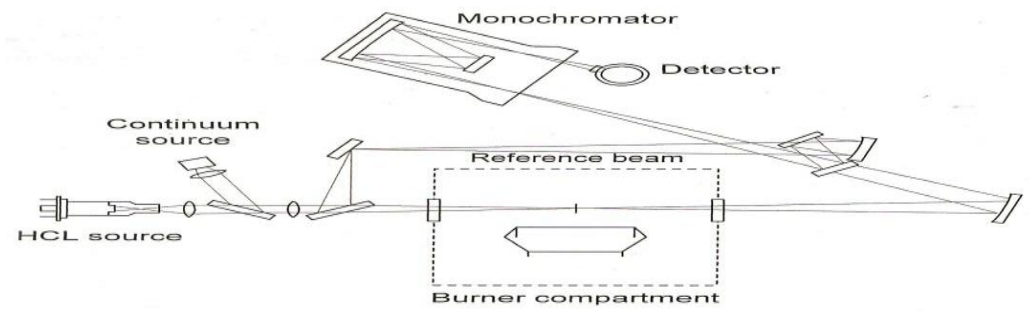

Fig. 4. 2: Optical arrangement of atomic absorption spectrophotometer

\section{Materials and Methods}

Blood sample of Duchenne muscular dystrophic patients along with normal healthy control were collected from the Department of Neurology, Safdarjang Hospital, New Delhi-110016 after the approval of ethical committee of the hospital. $10 \mathrm{ml}$ freshly drawn blood from each patient was collected in clean and dry test tube without any anti-coagulant. The test tube was kept for 45 minutes at room temperature $\left(22 \pm 2^{\circ} \mathrm{C}\right)$ for the formation of clot. Sera of different patients were separated by centrifugation at 1500 r.p.m. upto 15 minutes and were collected in screw capped test tubes.

The atomic absorption spectral estimation of the serum samples from normal persons and epileptic patients were carried out on atomic absorption spectrophotometer Model No. AA- 6300 of Shimadzu Japan, at Deptt. of Environmental study University of Delhi 110007.

\section{RESULTS}

We have measured the values of trace elements such as $\mathrm{Cu}, \mathrm{Fe}, \mathrm{Zn}, \mathrm{Na}, \mathrm{K}, \mathrm{Ca}$, Se and $\mathrm{Mg}$, in Duchenne muscular dystrophic patients and healthy normal control given in Table No. 1 along with the latest availability of the literature.

Table 6.1 : Results along with work carried out by researchers on different mode of analysis using different types of samples and diseases.

\begin{tabular}{|c|c|c|c|c|c|}
\hline $\begin{array}{l}\text { S. } \\
\text { No. }\end{array}$ & $\begin{array}{c}\text { Trace elemental } \\
\text { parameters }\end{array}$ & $\begin{array}{l}\text { Types of } \\
\text { Samples }\end{array}$ & Mean $\pm S . D$ Unit & Disease/Control & Reference \\
\hline 1 & Calcium & Serum & $(9.0 \pm 0) \mathrm{mg} / 100 \mathrm{ml}$ & \multirow[t]{2}{*}{ Epileptic } & John, H. et. al.[149] \\
\hline 2 & Calcium & Serum & $(10.47 \pm 1.16) \mu \mathrm{g} / \mathrm{dl}$ & & \multirow[t]{2}{*}{ Prasad, R. et.al. [150] } \\
\hline 3 & Calcium & Serum & $(10.76 \pm 3.29) \mu \mathrm{g} / \mathrm{dl}$ & \multirow[t]{2}{*}{ Controls } & \\
\hline 4 & Calcium & Hair & $(906 \pm 796) \mu \mathrm{g} / \mathrm{g}$ & & \multirow[t]{2}{*}{ Lech, T. et.al. [151] } \\
\hline 5 & Calcium & Hair & $(520 \pm 436) \mu \mathrm{g} / \mathrm{g}$ & Neurological disorders & \\
\hline 6 & Calcium & Hair & $(960 \pm 419) \mu \mathrm{g} / \mathrm{g}$ & \multirow[t]{2}{*}{ Controls } & \multirow[t]{4}{*}{ Avci et.al. [152] } \\
\hline 7 & Calcium & Hair & $(1162 \pm 533) \mu \mathrm{g} / \mathrm{g}$ & & \\
\hline 8 & Calcium & Hair & $(947 \pm 850) \mu \mathrm{g} / \mathrm{g}$ & \multirow[t]{2}{*}{ Epileptic } & \\
\hline 9 & Calcium & Hair & $(1143 \pm 437) \mu \mathrm{g} / \mathrm{g}$ & & \\
\hline 10 & Calcium & CSF & $(6.47 \pm 0.87) \mu \mathrm{g} / \mathrm{dl}$ & Controls & \multirow[t]{2}{*}{ Prasad, R. et.al.[150] } \\
\hline 11 & Calcium & CSF & $(5.85 \pm 2.49) \mu \mathrm{g} / \mathrm{dl}$ & Epileptic & \\
\hline 12 & Calcium & Serum & $(2.46 \pm 0.09) \mu \mathrm{g} / \mathrm{dl}$ & Controls & \multirow[t]{4}{*}{ Barlow, P. J. et.al. [153] } \\
\hline 13 & Calcium & Serum & $(2.41 \pm 0.08) \mu \mathrm{g} / \mathrm{dl}$ & \multirow[t]{2}{*}{ Hyperactive children } & \\
\hline 14 & Calcium & Hair & $(430 \pm 200) \mu \mathrm{g} / \mathrm{g}$ & & \\
\hline 15 & Calcium & Hair & $(694 \pm 349) \mu \mathrm{g} / \mathrm{g}$ & Controls & \\
\hline 16 & Copper & Serum & $(38.119 \pm 2.68) \mu \mathrm{g} / \mathrm{dl}$ & Birth Asphyxia & \multirow[t]{2}{*}{ Khanna, R. S. et.al. [154] } \\
\hline 17 & Copper & Serum & $(29.677 \pm 1.611) \mu \mathrm{g} / \mathrm{dl}$ & Controls & \\
\hline
\end{tabular}


Sanjeev Kumar, Reena, Mittal, Sweety and D. C. Jain; Role of Trace Elements in Duchenne Muscular Dystrophy, Journal of Biomedical Engineering and Medical Imaging, Volume 1, No 5, Oct (2014) , pp 71-112

\begin{tabular}{|c|c|c|c|c|c|}
\hline 18 & Copper & Serum & $(2.328 \pm 0) \mathrm{mg} / \mathrm{dl}$ & Smokers & Adnan, M. et.al. [155] \\
\hline 19 & Copper & Serum & $(11.28 \pm 0) \mu \mathrm{mol}$ & Neurotoxic & Guidotti, T. L. et.al [156] \\
\hline 20 & Copper & Serum & $(112.9 \pm 41.88) \mu \mathrm{g} / \mathrm{dl}$ & Epileptic & Prasad, R. et.al.[150] \\
\hline 21 & Copper & Serum & $(66.46 \pm 9.76) \mu \mathrm{g} / \mathrm{dl}$ & \multirow[t]{3}{*}{ Controls } & \\
\hline 22 & Copper & Serum & $(111.22 \pm 13.06) \mathrm{mg} / \mathrm{l}$ & & Denitz, T. et. al. [157] \\
\hline 23 & Copper & Serum & $(112.65 \pm 9.33) \mathrm{mg} / \mathrm{l}$ & & \\
\hline 24 & Copper & Serum & $(114.55 \pm 7.38) \mathrm{mg} / \mathrm{l}$ & \multirow[t]{2}{*}{ Epileptic } & Denitz, T. et. al. [100] \\
\hline 25 & Copper & Serum & $(111.45 \pm 5.97) \mathrm{mg} / \mathrm{l}$ & & \\
\hline 26 & Copper & Serum & $(0.86 \pm 0.24) \mathrm{mg} / \mathrm{l}$ & \multirow[t]{3}{*}{ Controls } & Soylak, M. et.al. [158] \\
\hline 27 & Copper & Hair & $(19 \pm 7) \mu \mathrm{g} / \mathrm{g}$ & & \multirow[t]{4}{*}{ Avci et.al. [152] } \\
\hline 28 & Copper & Hair & $(16 \pm 8) \mu \mathrm{g} / \mathrm{g}$ & & \\
\hline 29 & Copper & Hair & $(14 \pm 9) \mu \mathrm{g} / \mathrm{g}$ & \multirow[t]{2}{*}{ Epileptic } & \\
\hline 30 & Copper & Hair & $(10 \pm 2) \mu \mathrm{g} / \mathrm{g}$ & & \\
\hline 31 & Copper & Serum & $(97.9 \pm 0) \mu \mathrm{g} / 100 \mathrm{ml}$ & Control & \multirow[t]{2}{*}{ Delvis, H.T. et. al. [159] } \\
\hline 32 & Copper & Serum & $(2.328 \pm 0) \mathrm{mg} / \mathrm{dl}$ & Neurological disorders & \\
\hline 33 & Copper & Serum & $(2.328 \pm 0) \mathrm{mg} / \mathrm{dl}$ & Control & \multirow[t]{2}{*}{ Kumar, S. et.al. [160] } \\
\hline 34 & Copper & Serum & $(2.328 \pm 0) \mathrm{mg} / \mathrm{dl}$ & GMF & \\
\hline 35 & Copper & Serum & $(2.328 \pm 0) \mathrm{mg} / \mathrm{dl}$ & Epileptic & \multirow[t]{2}{*}{ Smith and Bone [161] } \\
\hline 36 & Copper & Serum & $(2.328 \pm 0) \mathrm{mg} / \mathrm{dl}$ & \multirow[t]{2}{*}{ Control } & \\
\hline 37 & Copper & CSF & $(66.46 \pm 9.76) \mu \mathrm{g} / \mathrm{dl}$ & & \multirow[t]{2}{*}{ Prasad, R. et. al. [150] } \\
\hline 38 & Copper & CSF & $(66.46 \pm 9.76) \mu \mathrm{g} / \mathrm{dl}$ & \multirow[t]{2}{*}{ Epileptic } & \\
\hline 39 & Copper & Serum & $(66.46 \pm 9.76) \mu \mathrm{g} / \mathrm{dl}$ & & \multirow[t]{2}{*}{ Kaji, H. et. al. [162] } \\
\hline 40 & Copper & Serum & $(66.46 \pm 9.76) \mu \mathrm{g} / \mathrm{dl}$ & Control & \\
\hline 41 & Copper & Hair & $(14 \pm 9) \mu \mathrm{g} / \mathrm{g}$ & Hyperactive children & \multirow[t]{2}{*}{ Barlow, P. J. et. al. [153] } \\
\hline 42 & Copper & Hair & $(14 \pm 9) \mu \mathrm{g} / \mathrm{g}$ & Control & \\
\hline 43 & Iron & Serum & $\begin{array}{c}(108.636 \pm 13.03) \\
\mu \mathrm{g} / \mathrm{dl}\end{array}$ & Birth Asphyxia & \multirow[t]{2}{*}{ Khanna, R. S. et.al. [154] } \\
\hline 44 & Iron & Serum & $(91.469 \pm 2.42) \mu \mathrm{g} / \mathrm{dl}$ & \multirow[t]{3}{*}{ Controls } & \\
\hline 45 & Iron & Hair & $(9 \pm 2) \mu \mathrm{g} / \mathrm{g}$ & & \multirow[t]{4}{*}{ Avci et.al. [152] } \\
\hline 46 & Iron & Hair & $(15 \pm 9) \mu \mathrm{g} / \mathrm{g}$ & & \\
\hline 47 & Iron & Hair & $(6 \pm 4) \mu g / g$ & \multirow[t]{2}{*}{ Epileptic } & \\
\hline 48 & Iron & Hair & $(7 \pm 5) \mu \mathrm{g} / \mathrm{g}$ & & \\
\hline 49 & Iron & Serum & $(386.0 \pm 0) \mu \mathrm{g} / 100 \mathrm{ml}$ & Controls & \multirow[t]{2}{*}{ Delvis, H.T. et. al. [159] } \\
\hline 50 & Iron & Serum & $(373.4 \pm 0) \mu \mathrm{g} / 100 \mathrm{ml}$ & Neurological disorders & \\
\hline 51 & Iron & Serum & $(20 \pm 8) \mathrm{mg} / \mathrm{dl}$ & Control & Kumar, S. et.al. [160] \\
\hline 52 & Iron & Serum & $(29 \pm 15) \mathrm{mg} / \mathrm{dl}$ & GMF & \\
\hline 53 & Iron & Hair & $(8.8 \pm 3.0) \mu \mathrm{g} / \mathrm{g}$ & Hyperactive children & Barlow, P. J. et.al. [153] \\
\hline 54 & Iron & Hair & $(15.7 \pm 10.6) \mu \mathrm{g} / \mathrm{g}$ & Controls & \\
\hline 55 & Magnesium & Serum & $(0.87 \pm 0.34) \mu \mathrm{g} / \mathrm{dl}$ & Epileptic & Prasad, R. et. al. [150] \\
\hline 56 & Magnesium & Serum & $(0.93 \pm 0.18) \mu \mathrm{g} / \mathrm{dl}$ & Controls & \\
\hline 57 & Magnesium & Serum & $(24.13 \pm 0.81) \mathrm{mg} / \mathrm{l}$ & Epileptic & Denitz, T. et. al. [157] \\
\hline 58 & Magnesium & Serum & $(19.44 \pm .53) \mathrm{mg} / \mathrm{l}$ & & \\
\hline 59 & Magnesium & Serum & $(24.33 \pm 2.74) \mathrm{mg} / \mathrm{l}$ & Controls & \\
\hline 60 & Magnesium & Serum & $(19.50 \pm 0.64) \mathrm{mg} / \mathrm{l}$ & & \\
\hline 61 & Magnesium & Hair & $(40.5 \pm 32.9) \mu \mathrm{g} / \mathrm{g}$ & & Lech, T. et.al. [51] \\
\hline 62 & Magnesium & Hair & $(29.3 \pm 25.3) \mu \mathrm{g} / \mathrm{g}$ & Neurological disorders & \\
\hline 63 & Magnesium & Hair & $(259 \pm 76) \mu \mathrm{g} / \mathrm{g}$ & Controls & Avci et.al. [152] \\
\hline 64 & Magnesium & Hair & $(505 \pm 219) \mu \mathrm{g} / \mathrm{g}$ & & \\
\hline 65 & Magnesium & Hair & $(329 \pm 285) \mu \mathrm{g} / \mathrm{g}$ & Epileptic & \\
\hline 66 & Magnesium & Hair & $(444 \pm 203) \mu \mathrm{g} / \mathrm{g}$ & & \\
\hline 67 & Magnesium & CSF & $(1.31 \pm 0.18) \mu \mathrm{g} / \mathrm{dl}$ & Controls & Prasad, R. et. al. [150] \\
\hline 68 & Magnesium & CSF & $(1.03 \pm 0.58) \mu \mathrm{g} / \mathrm{dl}$ & Epileptic & \\
\hline 69 & Magnesium & Serum & $(0.80 \pm 0.04) \mu \mathrm{mol} / \mathrm{l}$ & Controls & Smith and Bone [161] \\
\hline 70 & Magnesium & Serum & $(0.80 \pm 0.06) \mu \mathrm{mol} / \mathrm{l}$ & Epileptic & \\
\hline 71 & Magnesium & Hair & $(53.9 \pm 36.9) \mu \mathrm{g} / \mathrm{g}$ & Hyperactive children & Barlow, P. J. et. al. [153] \\
\hline 72 & Magnesium & Hair & $(67.5 \pm 47.4) \mu \mathrm{g} / \mathrm{g}$ & Controls & \\
\hline 73 & Zinc & Serum & $(99.523 \pm 7.44) \mu \mathrm{g} / \mathrm{dl}$ & Birth Asphyxia & Khanna, R. S. et.al. [154] \\
\hline
\end{tabular}


Journal of Biomedical Engineering and Medical Imaging, Volume 1, Issue 5, October, 2014

\begin{tabular}{|c|c|c|c|c|c|}
\hline 74 & Zinc & Serum & $(91.497 \pm 2.44) \mu \mathrm{g} / \mathrm{dl}$ & Controls & \\
\hline 75 & Zinc & Serum & $(3.214 \pm 0) \mathrm{mg} / \mathrm{l}$ & Smokers & Adnan, M. et.al. [155] \\
\hline 76 & Zinc & Serum & $(8.20 \pm 0) \mu \mathrm{mol}$ & Neurotoxic & Guidotti, T. L. et.al [156] \\
\hline 77 & Zinc & Serum & $(64.82 \pm 18.44) \mu \mathrm{g} / \mathrm{dl}$ & Epileptic & Prasad, R. et. al. [150] \\
\hline 78 & Zinc & Serum & $(99.0 \pm 8.0) \mathrm{mg} / \mathrm{l}$ & \multirow[t]{2}{*}{ Controls } & \multirow[t]{8}{*}{ Denitz, T. et. al. [157] } \\
\hline 79 & Zinc & Serum & $(85.90 \pm 2.79) \mathrm{mg} / \mathrm{l}$ & & \\
\hline 80 & Zinc & Serum & $(56.65 \pm 4.62) \mathrm{mg} / \mathrm{l}$ & \multirow[t]{2}{*}{ Epileptic } & \\
\hline 81 & Zinc & Serum & $(69.75 \pm 3.07) \mathrm{mg} / \mathrm{l}$ & & \\
\hline 82 & Zinc & Hair & $(134.0 \pm 9.41) \mu \mathrm{g} / \mathrm{g}$ & \multirow[t]{2}{*}{ Controls } & \\
\hline 83 & Zinc & Hair & $(136.59 \pm 8.56) \mu \mathrm{g} / \mathrm{g}$ & & \\
\hline 84 & Zinc & Hair & $(130.5 \pm 7.9) \mu \mathrm{g} / \mathrm{g}$ & \multirow[t]{2}{*}{ Epileptic } & \\
\hline 85 & Zinc & Hair & $(134.0 \pm 7.1) \mu \mathrm{g} / \mathrm{g}$ & & \\
\hline 86 & Zinc & Serum & $(0.54 \pm 0.21) \mathrm{mg} / \mathrm{l}$ & Controls & Soylak, M. et.al. [158] \\
\hline 87 & Zinc & Hair & $(200 \pm 61) \mu \mathrm{g} / \mathrm{g}$ & \multirow[t]{2}{*}{ Controls } & \multirow[t]{4}{*}{ Avci et.al. [152] } \\
\hline 88 & Zinc & Hair & $(218 \pm 87) \mu \mathrm{g} / \mathrm{g}$ & & \\
\hline 89 & Zinc & Hair & $(211 \pm 63) \mu \mathrm{g} / \mathrm{g}$ & \multirow[t]{2}{*}{ Epileptic } & \\
\hline 90 & Zinc & Hair & $(218 \pm 127) \mu \mathrm{g} / \mathrm{g}$ & & \\
\hline 91 & Zinc & Serum & $(510 \pm 0) \mu \mathrm{g} / 100 \mathrm{ml}$ & Controls & \multirow[t]{2}{*}{ Delvis, H.T. et. al. [159] } \\
\hline 92 & Zinc & Serum & $(617.9 \pm 0) \mu \mathrm{g} / 100 \mathrm{ml}$ & Neurological disorders & \\
\hline 93 & Zinc & Serum & $(16 \pm 9) \mathrm{mg} / \mathrm{dl}$ & GME & Kumar, S. et.al. [160] \\
\hline 94 & Zinc & Serum & $(13 \pm 2) \mathrm{mg} / \mathrm{dl}$ & Epilepsy & \multirow[t]{2}{*}{ Smith and Bone [161] } \\
\hline 95 & Zinc & Serum & $(14 \pm 2) \mathrm{mg} / \mathrm{dl}$ & \multirow[t]{2}{*}{ Controls } & \\
\hline 96 & Zinc & CSF & $(5.61 \pm 2.02) \mu \mathrm{g} / \mathrm{dl}$ & & \multirow[t]{2}{*}{ Prasad, R. et. al. [150] } \\
\hline 97 & Zinc & CSF & $(6.64 \pm 4.40) \mu \mathrm{g} / \mathrm{dl}$ & Epilepsy & \\
\hline 98 & Zinc & Serum & $(83.2 \pm 11.8) \mu \mathrm{g} / \mathrm{dl}$ & Hyperactive children & \multirow[t]{4}{*}{ Barlow, P. J. et. al. [153] } \\
\hline 99 & Zinc & Serum & $(87.6 \pm 12.4) \mu \mathrm{g} / \mathrm{dl}$ & Controls & \\
\hline 100 & Zinc & Hair & $(97.5 \pm 14.7) \mu \mathrm{g} / \mathrm{g}$ & Hyperactive children & \\
\hline 101 & Zinc & Hair & $(123.0 \pm 12.6) \mu \mathrm{g} / \mathrm{g}$ & Controls & \\
\hline 102 & Zinc & Serum & $(1.6875 \pm 1.8156) \mathrm{mg} / \mathrm{l}$ & Epilepsy & \multirow[t]{14}{*}{ Kumar, S. et.al. [163] } \\
\hline 103 & Zinc & Serum & $(1.0267 \pm 0.6347) \mathrm{mg} / \mathrm{l}$ & Controls & \\
\hline 104 & Calcium & Serum & $(4.0285 \pm 1.0521) \mathrm{mg} / \mathrm{l}$ & Epilepsy & \\
\hline 105 & Calcium & Serum & $(0.0483 \pm 0.0284) \mathrm{mg} / \mathrm{l}$ & Controls & \\
\hline 106 & Copper & Serum & $(0.1767 \pm 0.1087) \mathrm{mg} / \mathrm{l}$ & Epilepsy & \\
\hline 107 & Copper & Serum & $(0.1329 \pm 0.0380) \mathrm{mg} / \mathrm{l}$ & Controls & \\
\hline 108 & Iron & Serum & $(1.8483 \pm 1.8079) \mathrm{mg} / \mathrm{l}$ & Epilepsy & \\
\hline 109 & Iron & Serum & $(1.1826 \pm 1.7671) \mathrm{mg} / \mathrm{l}$ & Controls & \\
\hline 110 & Magnesium & Serum & $(4.7017 \pm 0.9548) \mathrm{mg} / \mathrm{l}$ & Epilepsy & \\
\hline 111 & Magnesium & Serum & $(0.1098 \pm 0.0310) \mathrm{mg} / \mathrm{l}$ & Controls & \\
\hline 112 & Potassium & Serum & $(0.1572 \pm 0.0098) \mathrm{mg} / \mathrm{l}$ & Epilepsy & \\
\hline 113 & Potassium & Serum & $(0.1443 \pm 0.0043) \mathrm{mg} / \mathrm{l}$ & Controls & \\
\hline 114 & Sodium & Serum & $(3.2271 \pm 0.0956) \mathrm{mg} / \mathrm{l}$ & Epilepsy & \\
\hline 115 & Sodium & Serum & $(3.1203 \pm 0.0708) \mathrm{mg} / \mathrm{l}$ & Controls & \\
\hline 116 & Zinc & Serum & $(0.325 \pm 0.155) \mathrm{mg} / \mathrm{l}$ & DMD & 1.1 Present work \\
\hline 117 & Zinc & Serum & $(1.072 \pm 0.616) \mathrm{mg} / \mathrm{l}$ & Control & Present work \\
\hline 118 & Calcium & Serum & $(0.154 \pm 0.032) \mathrm{ml} / \mathrm{l}$ & DMD & Present work \\
\hline 119 & Calcium & Serum & $(0.044 \pm 0.027) \mathrm{ml} / \mathrm{l}$ & Controls & Present work \\
\hline 120 & Copper & Serum & $(2.485 \pm 1.668) \mathrm{mg} / \mathrm{l}$ & DMD & Present work \\
\hline 121 & Copper & Serum & $(0.139 \pm 0.042) \mathrm{mg} / \mathrm{l}$ & Control & Present work \\
\hline 122 & Iron & Serum & $(11.086 \pm 6.628) \mathrm{mg} / \mathrm{l}$ & DMD & Present work \\
\hline 123 & Iron & Serum & $(1.122 \pm 1.177) \mathrm{mg} / \mathrm{l}$ & Control & Present work \\
\hline 124 & Magnesium & Serum & $(1.243 \pm 0.371) \mathrm{mg} / \mathrm{l}$ & DMD & Present work \\
\hline
\end{tabular}


Sanjeev Kumar, Reena, Mittal, Sweety and D. C. Jain; Role of Trace Elements in Duchenne Muscular Dystrophy, Journal of Biomedical Engineering and Medical Imaging, Volume 1, No 5, Oct (2014) , pp 71-112

\begin{tabular}{|c|c|c|c|c|c|}
\hline 125 & Magnesium & Serum & $(0.109 \pm 0.0309) \mathrm{mg} / \mathrm{l}$ & Control & Present work \\
\hline 126 & Potassium & Serum & $\begin{array}{c}(0.2097 \pm \\
0.0310) \mathrm{mg} / \mathrm{l}\end{array}$ & DMD & Present work \\
& & & $\begin{array}{c}(0.1371 \pm \\
0.0068) \mathrm{mg} / \mathrm{l}\end{array}$ & Control & Present work \\
\hline 127 & Potassium & Serum & & DMD & Present work \\
& & Serum & $(3.359 \pm 0.242) \mathrm{mg} / \mathrm{l}$ & Control & Present work \\
\hline 128 & Sodium & Serum & $(3.1096 \pm$ & & DMD \\
\hline 129 & Sodium & & $0.0931) \mathrm{mg} / \mathrm{l}$ & \\
& & Serum & $(0.1395 \pm$ & $0.0931) \mathrm{mg} / \mathrm{l}$ & Present work \\
\hline
\end{tabular}

Regression coefficient and multiple correlation coefficients were also given is the Table 6.2 and Table 6.3

Table 6.2: Regression and correlation coefficient studies on $\mathrm{Na}, \mathrm{K}, \mathrm{Ca}, \mathrm{Mg}, \mathrm{Zn}, \mathrm{Cu}, \mathrm{Fe}$ and Selenium in normal samples.

\begin{tabular}{|c|c|c|c|c|c|}
\hline Diagnosis & $\begin{array}{l}\text { Regression } \\
\text { coefficients }\end{array}$ & $\begin{array}{l}\text { Regression } \\
\text { equations }\end{array}$ & $\begin{array}{l}\text { Coefficient of } \\
\text { correlation }\end{array}$ & $\begin{array}{c}\text { Coefficient of } \\
\text { partial correlation }\end{array}$ & $\begin{array}{c}\text { Multiple } \\
\text { correlation } \\
\text { coefficient }\end{array}$ \\
\hline \multirow[t]{8}{*}{ Normal } & $\begin{array}{l}b_{\mathrm{KK}}=1.577 \\
b_{\mathrm{KNa}}=8.414\end{array}$ & $\begin{array}{c}\mathrm{Na}=1.577 \mathrm{~K}+ \\
2.8934 \\
\mathrm{~K}=8.414 \mathrm{Na}- \\
2.1874\end{array}$ & $r_{\mathrm{NaK}}=0.1152$ & $\begin{array}{l}r_{\mathrm{CaNaK}}=0.0585 \\
r_{\mathrm{CaNa}}=0.0167\end{array}$ & $\begin{array}{l}R_{\mathrm{NaKCa}_{2}}=0.0166 \\
R_{\mathrm{KNaCa}}=0.0135\end{array}$ \\
\hline & $\begin{array}{l}b_{\mathrm{CaMg}}=0.0332 \\
b_{\mathrm{MgCa}}=0.0436\end{array}$ & $\begin{array}{c}\mathrm{Ca}=0.0332 \mathrm{Mg}- \\
0.0403 \\
\mathrm{Mg}=0.0436 \mathrm{Ca}+ \\
0.1071\end{array}$ & $r_{\mathrm{Cav}}=-0.0381$ & $\begin{array}{l}r_{\mathrm{NaKCa}}=0.1161 \\
r_{\mathrm{MeNaK}}=-0.0687\end{array}$ & $\begin{array}{l}R_{\mathrm{CaKNa}}=0.0035 \\
R_{\mathrm{MgNaK}}=0.0740\end{array}$ \\
\hline & $\begin{array}{l}b_{\mathrm{CuFe}}=3.3043 \\
b_{\mathrm{FeCu}}=2.5950\end{array}$ & $\begin{aligned} & \mathrm{Cu}= 3.3043 \mathrm{Fe}- \\
& 3.568 \\
& \mathrm{Fe}= 2.5950 \mathrm{Cu}+ \\
& 0.7612\end{aligned}$ & $r_{\mathrm{CuFe}}=0.0926$ & $\begin{array}{l}r_{\mathrm{MgKNa}}=-0.2755 \\
r_{\mathrm{NaKMg}}=0.0935\end{array}$ & $\begin{array}{l}R_{\mathrm{NaMgK}}=0.0179 \\
R_{\mathrm{KMgNa}}=0.0777\end{array}$ \\
\hline & $\begin{array}{l}b_{\mathrm{CuZn}}=0.0204 \\
b_{\mathrm{ZnCs}}=4.4029\end{array}$ & $\begin{aligned} \mathrm{Cu}= & 0.0204 \mathrm{Zn}+ \\
& 0.1132 \\
\mathrm{Zn}= & 4.4029 \mathrm{Cu}+ \\
& 0.4599\end{aligned}$ & $r_{\mathrm{ZnFe}}=-0.4914$ & $\begin{array}{l}r_{\mathrm{ZnCuFe}}=0.3629 \\
r_{\mathrm{ZFeCu}}=0.4881\end{array}$ & $\begin{array}{l}R_{\mathrm{CuFeZn}}=0.2416 \\
R_{\mathrm{FeClZn}}=0.2447\end{array}$ \\
\hline & $\begin{array}{l}b_{\mathrm{keZn}}=-0.938 \\
b_{\mathrm{mFe}}=-0.2571\end{array}$ & $\begin{aligned} \mathrm{Fe}= & -0.938 \mathrm{Zn}+ \\
& 2.1275 \\
\mathrm{Zn}= & -0.2571 \mathrm{Fe}+ \\
& 13604\end{aligned}$ & $r_{\mathrm{Cu} Z \mathrm{n}}=0.3002$ & $r_{\mathrm{Cure} Z \mathrm{n}}=0.2890$ & $R_{\mathrm{ZnFeCs}}=0.3620$ \\
\hline & $\begin{array}{c}b z_{n . S e}=0.7293 \\
b_{\text {sezn }}=0.0272\end{array}$ & $\begin{aligned} \mathrm{Zn}= & 0.7293 \mathrm{Se}+ \\
& 0.9275 \\
\mathrm{Se}= & 0.0272 \mathrm{Zn}+ \\
& 1.018\end{aligned}$ & $r$ ZnSe $=0.1409$ & $r \mathrm{ZnFeSe}=-0.4757$ & $R_{\mathrm{ZnFeSe}}=0.1661$ \\
\hline & & & $7 \mathrm{FeSe}=-0.3130$ & & \\
\hline & & & rCu.Se $=-0.1300$ & & \\
\hline
\end{tabular}


Table 6.3 : Regression and correlation coefficient studies on $\mathrm{Na}, \mathrm{K}, \mathrm{Ca}, \mathrm{Mg}, \mathrm{Zn}, \mathrm{Cu}$, Fe and Selenium in DMD samples.

\begin{tabular}{|c|c|c|c|c|c|}
\hline Diagnosis & $\begin{array}{l}\text { Regression } \\
\text { coefficients }\end{array}$ & Regression equations & $\begin{array}{l}\text { Coefficient of } \\
\text { correlation }\end{array}$ & $\begin{array}{l}\text { Coefficient of } \\
\text { partial } \\
\text { correlation }\end{array}$ & $\begin{array}{l}\text { Multiple } \\
\text { correlation } \\
\text { coefficient }\end{array}$ \\
\hline \multirow[t]{8}{*}{ DMD } & $\begin{array}{l}b_{\mathrm{Na} . \mathrm{K}}=3.0509 \\
b_{\mathrm{K} . \mathrm{Na}}=0.06319\end{array}$ & $\begin{array}{l}\mathrm{Na}=3.8509 \mathrm{~K}+2.5514 \\
\mathrm{~K}=0.6319 \mathrm{Na}-1.9128\end{array}$ & $r_{\mathrm{NaK}}=0.4933$ & $\begin{array}{l}r_{\mathrm{CaNa} . \mathrm{K}}=- \\
0.3099 \\
r_{\mathrm{CaK} . \mathrm{Na}}=0.3577\end{array}$ & $\begin{array}{l}R_{\mathrm{Na} . \mathrm{KCa}} \\
0.3160 \\
R_{\mathrm{K} . \mathrm{NaCa}} \\
0.3401 \\
\end{array}$ \\
\hline & $\begin{array}{l}b_{\mathrm{Ca} . \mathrm{Mg}}=0.0611 \\
b_{\mathrm{Mg} . \mathrm{Ca}}=8.2130\end{array}$ & $\begin{array}{l}\mathrm{Ca}=0.0611 \mathrm{Mg}+0.0780 \\
\mathrm{Mg}=8.2130 \mathrm{Ca}-0.0218\end{array}$ & $r_{\mathrm{CaMg}}=0.7084$ & $\begin{array}{l}r_{\mathrm{NaK} . \mathrm{Ca}}=0.5182 \\
r_{\mathrm{MgNa.K}}=0.1690\end{array}$ & $\begin{array}{l}R_{\mathrm{Ca} . \mathrm{KNa}} \\
0.1464 \\
R_{\mathrm{Mg} . \mathrm{NaK}} \\
0.0334\end{array}$ \\
\hline & $\begin{array}{c}b_{\mathrm{Cu} . \mathrm{Fe}}=- \\
0.1272 \\
b_{\mathrm{Fe} . \mathrm{Cu}}=- \\
2.0094\end{array}$ & $\begin{array}{c}\mathrm{Cu}=-0.1272 \mathrm{Fe}+3.8951 \\
\mathrm{Fe}=-2.0094 \mathrm{Cu}+16.0793\end{array}$ & $\begin{array}{l}r_{\mathrm{CuFe}} \\
0.5057\end{array}=$ & $\begin{array}{l}r_{\mathrm{MgK} . \mathrm{Na}}=-0.02 \\
19 \\
r_{\mathrm{NaK} . \mathrm{Mg}}=0.4897\end{array}$ & $\begin{array}{l}R_{\mathrm{Na} . \mathrm{MgK}} \\
0.2437 \\
R_{\mathrm{K} . \mathrm{MgNa}} \\
0.2649 \\
\end{array}$ \\
\hline & $\begin{array}{c}b_{\mathrm{Cu} . \mathrm{Zn}}=- \\
1.0944 \\
b_{\mathrm{Zn} . \mathrm{Cu}}=- \\
9.4505\end{array}$ & $\begin{array}{c}C u=-1.0944 Z n+2.8406 \\
Z n=-9.4505 C u+23.8094\end{array}$ & $r_{\mathrm{FeZn}}=0.5365$ & $\begin{array}{l}r_{\mathrm{ZnCu.Fe}}=0.2329 \\
r_{\mathrm{ZnFe.Cu}}=0.5651\end{array}$ & $\begin{array}{l}R_{\mathrm{Cu} . \mathrm{FeZn}} \\
0.2961 \\
R_{\mathrm{Fe} . \mathrm{CuZn}} \\
0.2447 \\
\end{array}$ \\
\hline & $\begin{array}{c}b_{\mathrm{Fe} . \mathrm{Zn}}=22.9414 \\
b_{\mathrm{Zn} \cdot \mathrm{Fe}}=0.0125\end{array}$ & $\begin{array}{c}\mathrm{Fe}=22.9414 \mathrm{Zn}+3.6300 \\
\mathrm{Zn}=0.0125 \mathrm{Fe}+0.1864\end{array}$ & $\begin{array}{l}r_{\mathrm{CuZn}} \\
0.1017\end{array}=-$ & $\begin{array}{l}r_{\text {CuFe.Zn }}=- \\
0.6673\end{array}=-$ & $\begin{array}{l}R_{\mathrm{Zn} \cdot \mathrm{FeCu}} \\
0.3265\end{array}$ \\
\hline & $\begin{array}{c}b \mathrm{Zn.Se}=- \\
0.3576 \\
b_{\text {Se.Zn }}=-0.1561\end{array}$ & $\begin{array}{l}Z n=-0.3576 S e+0.3748 \\
S e=-0.1561 Z n+0.1887\end{array}$ & $\begin{array}{l}\mathrm{ZZn} \cdot \mathrm{Se}=- \\
.2363\end{array}$ & $\begin{array}{l}r \mathrm{ZnFe} . \mathrm{Se}= \\
0.5021\end{array}$ & $R_{\mathrm{Zn} . \mathrm{FeSe}}=0.2939$ \\
\hline & & & $r_{\mathrm{Fe} . \mathrm{Se}}=-0.5607$ & & \\
\hline & & & $r \mathrm{Cu} . \mathrm{Se}=0.1631$ & & \\
\hline
\end{tabular}

\section{Discussion}

The estimation of trace elements show a colorful presentation of different metals .It has been seen and found that the levels of zinc and selenium were lower in DMD cases in comparison to healthy controls. The elements such as copper, calcium, iron, magnesium, potassium, sodium were found higher than controls.

On the basis of statistical analysis we have measured regression and correlation coefficients including multiple correlation coefficients between different trace elements like $\mathrm{Na}, \mathrm{K}, \mathrm{Ca}, \mathrm{Mg}, \mathrm{Zn}, \mathrm{Cu}, \mathrm{Fe}$ and Selenium in normal samples. A trend has been found in coefficient of correlation such as 
Sanjeev Kumar, Reena, Mittal, Sweety and D. C. Jain; Role of Trace Elements in Duchenne Muscular Dystrophy, Journal of Biomedical Engineering and Medical Imaging, Volume 1, No 5, Oct (2014) , pp 71-112

$r_{\mathrm{CuZn}}>r_{\mathrm{NaK}}>r_{\mathrm{Zn} . \mathrm{Se}}>r_{\mathrm{CuFe}}$ with positive correlation and $\quad r_{\mathrm{ZnFe}}>r_{\mathrm{FF} . \mathrm{Se}}>r_{\mathrm{Cu} . \mathrm{Se}}>r_{\mathrm{CaMg}}$ with negative correlation. Coefficient of partial correlation is also calculated and found that a trend has been set up between trace elements and given here as $r_{\mathrm{ZnFe} . \mathrm{Cu}}>r_{\mathrm{ZnCu} . \mathrm{Fe}}>r_{\mathrm{CuFe} . \mathrm{Zn}}>r_{\mathrm{NaK} . \mathrm{Ca}}>r_{\mathrm{CaNa.K}}>r_{\mathrm{CaK} . \mathrm{Na}}>$ $r_{\text {NaK.Mg }}$ with positive correlation and we have found also a negative correlation between some of the elements and a trend is given here as $r \mathrm{ZnFe.Se}>r_{\mathrm{MgK.Na}}>r_{\mathrm{MgNa.K}}$ Multiple correlation coefficient in normal healthy person has been estimated and found that a trend, which is given here as

$$
R_{\mathrm{Zn} . \mathrm{FeCu}}>R_{\mathrm{Fe} . \mathrm{CuZn}}>R_{\mathrm{Cu} . \mathrm{FeZn}}>R_{\mathrm{Zn} . \mathrm{FeSe}}>R_{\mathrm{K} . \mathrm{MgNa}}>R_{\mathrm{Mg} . \mathrm{NaK}}>R_{\mathrm{Na} \cdot \mathrm{MgK}}>R_{\mathrm{K} . \mathrm{NaCa}}>R_{\mathrm{K} . \mathrm{NaCa}}>R_{\mathrm{Ca} . \mathrm{KNa}}
$$

We have also measured correlation coefficients including multiple correlation coefficients between different types of trace elements like $\mathrm{Na}, \mathrm{K}, \mathrm{Ca}, \mathrm{Mg}, \mathrm{Zn}, \mathrm{Cu}, \mathrm{Fe}$ and Selenium in DMD samples.

A trend has been found in coefficient of correlation such as ${ }^{\mathrm{CaMg}_{>}}>r_{\mathrm{FeZn}}>r_{\mathrm{NaK}}>r_{\mathrm{Cu} . \mathrm{Se}}$ with positive correlation and $r_{\mathrm{Fe} . \mathrm{Se}}>r_{\mathrm{CuFe}}>r \mathrm{Zn}$.Se $>r_{\mathrm{CuZn}}$ with negative correlation. Coefficient of partial correlation is also calculated and found that a trend has been set up between trace elements and given here as $r_{\mathrm{CuFe.Zn}}>r_{\mathrm{CaNa.K}}>r_{\mathrm{MgK} . \mathrm{Na}}$ with negative correlation and also found a trend of positive correlation as $r_{\mathrm{ZnFeCu}}>r_{\mathrm{NaK} . \mathrm{Ca}}>r_{\mathrm{ZnFe} . \mathrm{Se}}>r_{\mathrm{NaK} . \mathrm{Mg}}>r_{\mathrm{CaK} . \mathrm{Na}}>r_{\mathrm{MgNa} . \mathrm{K}}$.

Multiple correlation coefficient in DMD patients has been estimated and found that a trend, which is given here as $R_{\mathrm{Fe} . \mathrm{CuZn}}>R_{\mathrm{K} . \mathrm{NaCa}}>R_{\mathrm{Zn} \text {.FeCu }}>R_{\mathrm{Na} . \mathrm{KCa}}>R_{\mathrm{Zn} . \mathrm{FeSe}}>R_{\mathrm{K} . \mathrm{MgNa}}>R_{\mathrm{Cu} . \mathrm{FeZn}}>R_{\mathrm{Na} . \mathrm{MgK}}>R_{\mathrm{Ca} . \mathrm{KNa}}>$ $R_{\mathrm{Mg} . \mathrm{NaK}}$.Many of the essential elements are required for human health and occasionally the margin between minimum needs and maximum tolerance of is very feeble. The chemical form of the trace element and the interactions between different trace elements included in the diet are also important in deciding between health and hazard. If we are able to monitor foods and environment for the effects of pollution therefore demands subtly and an awareness of the complexity. It has been apparent that many trace elements play an important role in the maintenance of human health and that an imbalance in trace elements may be a significant factor in a number of physical and neurological conditions. The imbalance may occur as an excess of an element or a deficiency of an element. Most of the elements can become toxic if the level in the body rises above a minimum or standard value.

The importance of nutritional states in maintaining the physical well-being of the human system is very well understandable but the role of diet, including metabolism of dietary constituents is much less well understood. Let us now examine the importance and relevance of the results obtained by us in DMD and the possible mechanisms.

Trace elements act as catalytic agents for enzyme systems of the cells. These elements play a role in enzyme reactions range from weak, ionic strength effects to highly specific associations known as Metalloenzymes. Metal is firmly associated with the protein and there is a fixed number of atoms per molecule of protein which cannot be removed from this association by dialysis. Removal of the metal by 
more drastic means leads to loss in the activity of enzyme. This loss cannot be restored readily either by re-addition of the metal.

The minimum requirements of living creatures for the essential trace elements are expressed in proportions or concentrations of the total dry food taken daily. The maximum intake of elements within the normal limits of the human body is called tolerance. The tolerance may be related as the fertility, growth, health or other relevant criteria of different dietary mineral concentrations.

There are safe dietary levels of potentially toxic trace elements. These depend on the extent to which other elements are present.

It may be probably related to the inhibition of Na-K ATPase activity. We must take care of our body not to take these two elements in sufficient amount. We must take proper intake of the copper and zinc enrich diet of our food.

It has been reported in the literature for the importance of trace metals which may have a role to play in the production of seizures and their control in human beings. Zinc, magnesium and copper also play an important biochemical role in the human metabolism.

It has been reviewed and reported in the literature that the living things need 72 biological elements for normal metabolic function, reproduction, and maintenance of the immune system. Calcium is an element which is generally deficient. It is required in every cell in our body and vitally important. If the food is grown on soils which contain all the 72 elements, we may say it is healthy food. Insects and diseases do not attack plants grown in healthy soil. Insects are nature's garbage disposal agents. We choose to kill insects and allow ourselves to eat garbage. Disease is also nature's way of eliminating those things that are not healthy. They may plants, animals and humans.

Food we eat is deficient in over sixty vitally important elements. The food which is deficient to all such types of elements is the basic cause of large numbers of physiological and mental diseases such as auto immune disease, late onset diabetes, degenerative and chronic diseases, allergies and birth defects and neurological disorders.

It has been established in the literature that the routine cocktail of medications with their complicated interactions and side effects should be rejected. We must provide a chance for minerals, vitamins and essential fatty acids and trace elements for healthy body.

Trace elements are essential in the assimilation and utilization of vitamins. Elements help in the digestion. The elements work as a catalyst for hormones and enzymes. They may work as an aid in replacing electrolytes lost through perspiration. Elements protect against toxic reactions.

Reinstatement of trace elements in our soils eliminates all plant diseases, pests and insect attacks. This eliminates the need for use of toxic agricultural chemicals. We may have a healthy food rather than a food which is deficient to all the trace elements. We must try to keep maintain the levels of zinc and selenium on the higher values up to the normal values. The levels of elements such as copper, calcium, iron, magnesium, potassium, sodium may be put on the lower side of normal values.

We know that living organisms, including humans, are part of environment they reflect what is present in their surroundings. Traces of a large variety of both natural and man-made compounds can be found 
Sanjeev Kumar, Reena, Mittal, Sweety and D. C. Jain; Role of Trace Elements in Duchenne Muscular Dystrophy, Journal of Biomedical Engineering and Medical Imaging, Volume 1, No 5, Oct (2014) , pp 71-112

in the tissues and fluids of humans as a result of exposure to these compounds in air, soil, water, food and consumer products.

Evidences from analysis of foods and water, as well as from direct measurements of fluids and tissues, reveals that the levels of some harmful elements have decreased now a days.

We are able to detect a number of compounds in the human body that results from the use of consumer products, such as pharmaceuticals and dietary supplements, and from lifestyle choices, such as smoking and alcoholism.

The continuous detection of trace elements in human tissues and fluids has led to legitmate concern about the possible health effects of the presence of elements in human body. To evaluate this fact, it is important to understand how these elements are detected, what trends are in the levels, and what is known about the health impacts of the levels that have been detected.

\section{Conclusion}

The chemical form of trace element and interactions between different types of trace elements included in the food are very important in deciding between hazard and health. The imbalance of the levels of elements may be adjusted with the proper medication monitoring. Trace elements may act as catalytic agents for enzyme system of the cells. The minimum requirements of living objects for essential trace elements may be expressed in proportions or concentration of the total dry food taken every day. A tolerance of the human system may be adjusted according to intake of these elements. Tolerance is related to the immunity of our human system. If the tolerance is on the lower side of normalcy the immunity may be decreased. We must increase the immunity with the adjustment of proper food and supplementation of suitable trace elements.

Routine use of medicines in bulk with side effects must avoid. We can take minerals, vitamins and essential fatty acids with proper trace elements for healthy human system. A continuous monitoring of trace elements in human tissues and fluids has led to legitimate concern about the probable effects of the presence of trace elements in human system. Our findings suggest that the values of higher levels of trace elements should be adjusted such that these levels must slight below or equal to the normal limits of the particular element. The levels of zinc and selenium should be maintained within the normal limits for DMD cases in comparison to healthy controls. The elements such as copper, calcium, iron, magnesium, potassium, sodium may be reduced up to the normal limits in comparison to healthy persons .

\section{ACKNOWLEDGEMENTS}

Authors are thankful to Dr. P. K. Saxena Principal, D.A.V. College, Muzaffarnagar, U.P. for providing necessary conditions to carry research. 


\section{REFERENCES}

[1]. Petrof, B., Shrager, J., Stedman, H., Kelley, A. and Sweeney, H. (1993) : Dystrophin protects the sarcolemma from stresses developed during muscle contraction. Medical. Sciences, 90, Retrived from http:// www. pnas. org/content/90/8/3710.full.pdf.

[2]. Emery, A. E. (2002) : The muscular dystrophies. Lancet, 359 (9307), 687.

[3]. Bach, R. J. (1999) : Introduction In : Guide to the evaluation and management of neuro muscular disease. Hanley \& Belfus. Inc. Philadelphia P. A. , pp. 1-4.

[4]. Meryon, E. (1852) : On grannular and fatty degeneration of the voluntary muscles, Med. Chir. Trans. 35, 72- 84

[5]. Duchenne, G. B. A. (1868) : Researches Sur la paralysic musculaire pseudo hypertrophic or paralysie myosclero sique, Arch. Gen. Med., 11, 5- 25.

[6]. Maser, H. (1984) : Duchenne muscular dystrophy : Pathogenetic aspects and genetic prevention. Hum. Genet., 66, 17-40.

[7]. Emery, A. E. (1991): Population frequencies of inherited neuromuscular disease - a world survey. Neuromuscular. Disord. 1(1), 19-29.

[8]. Abood, E. A., Jones, M. M. (1991) : Macrophages in developing mammalian skeletal muscle : evidence for muscle fibre death as a normal developmental event. Acta. Anat (Basel) 140 (3), 201-212.

[9]. Simonds, A. K., Muntani, F., Heather, S., Fielding, S. (1998) : Impact of nasal ventilation on survival in hypercapnic Duchenne muscular dystrophy, Therax, 53 (11), 949-952.

[10]. Somer, H., Donner, M., Murros, J., Konttinen, A. (1973) : A serum isoenzyme study in muscular dystrophy. Particular reference to creatine kinase, aspartate aminotransferase, and lactic acid dehydrogenase isozymes. Arct. Meyral, 29 (5), 343-345.

[11]. Mokri, B., Engel, A. G. (1975) : Duchenne dystrophy : electron microscopic findings pointing to a basic or early abnormality in the plasma membrane of muscle fibre. Neurology, 25 (12), 111-1120.

[12]. Engel, J., Furthmayr, H. Odermatt, E., Vender Mark, H., Aumailley, M., Fleischmajer, R., and Timpl, R. (1985) : Structure and macromolecular organization of type VI Collagen, Ann. N. Y. Acad. Sci., 460, 25-37.

[13]. Gillis, J. M. (1999) : Understanding dystrophinopathies : an inventory of the structural and functional consequences of the absence of dystrophin in muscles of the mdx mouse. J. Muscle. Res. Cell. Motil, 20 (7), 605-625.

[14]. Sandri, M., Minetti, C., Pedemonte, M., Carraro, U. (1998) : Apoptotic myonuclei in human Duchenne muscular dystrophy. Lab. Invest., 78 (8), 1005-1016.

[15]. Tidball, J. G., Albrecht, D. E., Lokensgal, B. E., Spencer, M. J. (1995): Apptasis precedes necrosis of dystrophin deficient muscle, J. Cell. Sci., 108 (6), 2197-2204. 
Sanjeev Kumar, Reena, Mittal, Sweety and D. C. Jain; Role of Trace Elements in Duchenne Muscular Dystrophy, Journal of Biomedical Engineering and Medical Imaging, Volume 1, No 5, Oct (2014) , pp 71-112

[16]. Matsuda, R., Nishikawa, A., Tanaka, H. (1995) : Visualization of dystrophic muscle fibers in mdx mouse by vital staining with Evans blue : evidence of apoptosis in dystrophin-deficient mouscle. J. Biochem (Tokye), 118 (5), 959-964.

[17]. Spencer, M. J., Walsh, C. M., Darsh kind, K. A., Rodriguez, E. M. and Tidball, J. G. (1997) : Myonuclear apoptosis in dystrophic mdx muscles occurs by perforin-mediated cytotoxicity. J. Clin. Invest., 99 (11), 2745-2751.

[18]. Bradley, W. G., Hudgson, P., Larson, P. F., Papapetropoulas, T. A. and Jenkison, M. (1972) : Structural changes in the early stages of Duchenne muscular dystrophy. J. Neurol. Neuro Surg. Psychiatry., 35 (4), 451-455.

[19]. Bowman, W. (1840) : On the minute structure and movements of voluntary muscle. Philos. Trans. R Soc. London. Biol., 130, 457- 501.

[20]. Murphy, D. L., Mendell, J. R. and Engel, W. K. (1973) : Serotonin and platelet function in Duchenne's muscular dystrophy. Arch. Neurol. 28, 239-242.

[21]. Paulsan, O. F., Engel, A. G. and Gomez, M. R. (1974) : Muscle blood flow in Duchenne type muscular dystrophy, limb-gridle dystrophy, polymyositis and in normal controls, J. Neurol. Neuroserg. Psychioatry, 37, 685-690.

[22]. Jerusalem, F., Engel, A. G. and Gomez, M. R. (1974) : Duchenne dystrophy. I. Morphometric study of the muscle micro vascular. Brain, 97, 115-122.

[23]. Mc Comas, A. J., Sica, R. E. P. and Currie, S. (1971) : An electrophysiological study of Duchenne dystrophy. J. Neurol. Neurosurg. Psychiatry, 34, 461-468.

[24]. Panayiotopoulos, C. P., Scarpalezos, S. and Papapetropoulos, T. (1974) : Electrophysiological estimation of motor units in Duchenne muscular dystrophy. J. Neurol. Sci., 23, 89-98.

[25]. Ballantyne, J. P. and Hansen, S. (1974) : New method for estimation of the number of motor units in a muscle. 2. Duchenne, limb-girdle and facioscapulohumerol, and myotonic muscular dystrophies. J. Neurol. Neurosurg. Psychiatry, 37, 1195-1201.

[26]. Matheson, D. M. and Howland, J. L. (1974) : Erythrocyte deformation in human muscular dystrophy. Science, 184, 165-166.

[27]. Miale, T. D., Frias, J. L. and Lawson, D. L. (1975) : Erythrocytes in human muscular dystrophy, Science 187, 453.

[28]. Miller, S. E., Roses, A. D. and Appel, S. H. (1975) : Erythrocytes in human muscular dystrophy, Science, 188, 1131.

[29]. Brown, H. D., Chattpadyay, S. K. and Patel, A. B. (1967) : Erythrocyte abnormality in human myopathy, Science, $157,1577-1578$.

[30]. Peter, J. B. Worsfold, M. and Pearson, C. M. (1969) : Erythrocyte ghost adenosine triphosphate (AT Pase) in Duchenne dystrophy. J. Lab. Clin. Med., 74, 103-108.

[31]. Roses, A. D., Herbstreith, M. H. and Appel, S. H. (1975) : Membrane protein kinease alteration in Duchenne muscular dystrophy. Nature, 254, 350-351. 
[32]. Mawatari, S., Takagi, A. and Rowland, L. P. (1974) : Adenyl cyclase in normal and pathologic human muscle, Arch Neurol. 30, 96-102.

[33]. Pearce, G. W., Pearce, J. M. S. and Walton, J. N. (1966) : The Duchenne type muscular dystrophy : Histopathological studies of the carrier state, Brain, 89, 109-120.

[34]. Roy, S. and Dubowitz, V. (1970) : Carrier detection in Duchenne muscular dystrophy, J. Neurol. Sci., 11, 65-79.

[35]. Ionasescu, V., Zellweger, H. and Conway,T. W. (1971) : Ribosomal protein synthesis in Ducheme muscular dystrophy, Arch. Bio Chem. Biophys., 144, 51-58.

[36]. Ionasescu, V., Zellweger, H. Shirk, P. and Conway, T. W. (1973) : Identification of carriers of Duchenne muscular dystrophy by muscle protein synthesis. Neurology, 23, 497-501.

[37]. Roses, A. D., Roses, M. J., Miller, S. E., Hull, K. L. and Appel, S. M. (1976) : Carrier detection in Duchenne muscular dystrophy. New. Engl. J. Med., 294, 193-197.

[38]. Hobbins, J. C. and Mahoney, M. J. (1974) : In utero diagnosis of hemoglobinopathies. Technique for obtaining fetal blood. New. Engl. J. Med., 290, 1065-1067.

[39]. Bodensteiner, J. B. and Engel, A. G. (1978) : Intracellular calcium accumulation in Duchenne dystrophy and other myopathies. A study of 56, 7,000 muscle fibers in 114 biopsies. Neurology, 28, 439-446.

[40]. Bertorini, T. E., Bhattacharya, S. K., Polmieri, G. M. A., Chesney, $\quad$ C. M., Bifer, D. and Baker, B. (1982) : Muscle calcium and magnesium content in Duchenne muscular dystrophy. Neurology, 32, 1088-1092.

[41]. Schotland, D. L., Bonilla, E. and Wakayama, Y. (1980): Application of the freeze fraeture technique to the study of human neuromuscular diseases, Muscle. Nerve., 3, 21-27.

[42]. Schotland, D. L., Bonilla, E. and Van Meter, M. (1977) : Duchenne dystrophy alteration in plasma membrane structure, Science, 196, 1005-1007.

[43]. Peluchretti, D., Mora, M., Protti, A. and Cornelio, F. (1985) : Freeze fracture analysis of the muscle fiber plasma membrane in Duchenne dystrophy, Neurology, 35, 928-930.

[44]. Heimann-Patterson, T. D., Bonilla, E., and Schotland, D. L. (1982) : Cancanavalin A binding of the Cell surfac of Duchenne muscle in vitro. Ann. Neurol., 12, 305-307.

[45]. Brooke, M. H. (1986) : Muscular dystrophies, In : A clinician's view of neuromuscular disease. Edited by Nancy, McSherry, C. and Victoria, M. V., Williams \& Wilkins, Baltimore, London Los Angles Sytdney. PP. 117-154.

[46]. Ionasescu, V., Ionaseesu, R., Feld, R., Write, D., Cancilla, P., Kaeding, L. and Stern, L. Z. (1991 : Alterations in creatine kinase in fresh muscle and cell cultures in Duchenne dystrophy. Ann. Neurol., 9, 394-399.

[47]. Thompson, E. J., Yasin, R., Vanbeer S. G., Nurse, K. and Al-Ani, S. (1977) : Myogenic defect in human muscular dystrophy, Nature, 268, 241-243. 
Sanjeev Kumar, Reena, Mittal, Sweety and D. C. Jain; Role of Trace Elements in Duchenne Muscular Dystrophy, Journal of Biomedical Engineering and Medical Imaging, Volume 1, No 5, Oct (2014) , pp 71-112

[48]. Rothman, S. M. and Bischoff, R. (1983) : Electrophysiology of Duchenne dystrophy myotubes in tissue culture. Ann. Neurol., 13, 176-179.

[49]. Mawatari, S., Miranda, A., and Rowland, L. P. (1976) : Adenyl Cyelase abnormality in Duchenne muscular dystrophy : muscle cells in culture, Neurology, 26, 1021-1026.

[50]. Cerri, C. A., Willner, J. H., and Miranda, A. F. (1982) : Adenylate cyclase in Duchenne fibroblasts. J. Neurol. Sci., 53, 181-185.

[51]. Rowland, L. P. (1980) : Biochemistry of muscle membranes in Duchenne dystrophy, Muscle. Nerve., 3, 3-20.

[52]. Falk, R. S., Campion, D., Guthrie, B., Sparkes, R. S. and Fox, C. F. (1979) : Phospharylation of the red cell membrane proteins in Duchenne muscular dystrophy. New. Engl. J. Med., 300, 258-259.

[53]. Fischer, S., Tortolero, M., Piau, J. P., Pelaunay, J. and Schapira, G. (1978) : Protein kinase and adanylate kinase of erythrocyte membrane from patients with Duchenne dystrophy. Clin. Chem. Acta., 88, 437-440.

[54]. Roses, A. D., Mabry, M. E., Herbstreith, M. H., Shile, E. V. and Balakrishnan, O. V. (1982) : Increased phospharylation of spectrin peptides in Duchenne muscular dystrophy. In : Disorders of the Motor Unit Edited by Schotland, D. L., John Wiley \& Sons, New York, PP. 413-420.

[55]. Mabry, M. E. and Roses, A. D. (1981) : Increased ${ }^{32}$ P-phashorylase of triptic peptides of erythrocytes spectrin in Duchenne muscular dystrophy Muscle Nerve, 4, 489-493.

[56]. Roses, A. D., Shile, P. E., Herbstreith, M. H. and Balakrishnan, C. V. (1981) : Identification of abnormality ${ }^{32}$ Pphashorylated cyanogen bromide cleavage product of erythrocyte membrane spectrin in Duchenne muscular dystrophy, Neurology, 31, 1026-1030.

[57]. Arthur, H., De Niese, M., Jeffrey, P. L. and Austin, L. (1983) : Plasma lipoprotein in Duchenne muscular dystrophy, Biochem. Int. 6, 307-313.

[58]. Personalhealthfacts. com (1985) : The importance of trace minerals, NFM'S, Nutrition Science, News , pp. 1-4.

[59]. Romeyn, M. (1998) : Vitamins, Minerals and Trace elements. In :Nutrition and HIV. Edited by Jossey-Bass Inc. Sonsome Street San Francisco.

[60]. Herring, W. B., Leavell, B. S., Paixao, L. M. and Yoe, J. H., (1960) : Trace metals in human plasma and red blood cells, American Journal of Clinical nutrition, Vol. 8, pp. 846-854.

[61]. Khurshid, S. J. and Qureshi, I. H. (1984) : The role of inorganic elements in human body, The Nucleus, Vol. 21, pp. 3-23.

[62]. Suhaila, R., Nasir, K., Shujaat, A., Nasim, U. and Mohammad, Z .I. (2004) : Essential trace metals in human whole blood in relation to environment, Pakistan J. Med. Res., Vol. 43, No. 2, pp. 1-5.

[63]. Kumar, S. (1989) : Medico-Physical studies on epilepsy and other neurological disorders, Ph.D. Thesis, University of Delhi, India. 
[64]. Mary, R. L. A., Kelvin, A. C., Sheila, D. and William, H. R. (2000) : Nutrient risk assessment implication for food fortification policy, In : Trace elements in man and animals, 10. Edited by Rousel, A. M., Anderson, R. A., Favrier, A., Kluwer Academic Publications, N. Y., Boston, Dodrecht, Lands, Moscow. pp 215 - 220

[65]. Alexander, G. S. (1995) : Minerals and Human health : The rationale for optimal and balanced trace element levels, Tacoma, Life. Sciences. Press. pp 1-5.

[66]. Pike, R. L. and Brown, M. L. (1984) : An Integrated Approach .In : Nutrition., John Wiley \& Sons, pp. 197.

[67]. Zumkley, H. (1987) : Trace elements in medicine, Fresenius Z., Anal Chem, Vol. 327, No. 1, pp. 6.

[68]. Davies, I. J. J. (1972) : Clinical significance of the essential biological metals, In: Animal health and hygiene (general), William Heineman, London, pp. 48- 26. I.S.B.N. 0433071702.

[69]. Burns, R. R. and Fell, G. S. (1976) : Estimation and interpretation of plasma zinc fractions, Secott. Med. J., Vol. 21, pp. 153-154.

[70]. Prasad, A. S., and Oberleas, D. (1970) : Binding of zinc to amino acids and serum proteins in vitro, J. Lab. Clin .Med., Vol. 76, No. 3, pp. 416-425.

[71]. Kelin, D. and Mann, J. (1940) : Carbonic anhydrase : Purification and nature of the enzyme, Biochem J, Vol. 34, No. 8\&9, pp. 1163-1176.

[72]. Riordan, J. F. and Vallee, B. L. (1976) : Structure and function of zinc metalloenzymes, In Trace Elements in human health and disease. $\quad$ Edited by Prasad, A. S. Vol. 1. Academic Press, New York, pp. $227-$ 251.

[73]. Chavapil, M., Zukowski, C. F., Hattler, B. G., Stankova, L., Montgomery, D., Carlson, E. C. and Ludwig, J. C. (1976) : Zinc and activity of cell membrane. In : Trace-elements in human health and disease. Edited by Prasad, A. S. Vol. 1, Academic Press, New York, pp. 269-281.

[74]. Prasad, A. S., Schulert, A. R., Sandstead, H. H., Miale. A. Jr., and Farid, Z., (1963): Zinc, iron and nitrogen content of sweat in normal and deficient subjects, J. Lab. Clin .Med., Vol. 62, pp. 84-89.

[75]. Walravens, P. A., Doornick, W. J. V. and Hambidge, K. M. (1978) : Metals and Mental Function, J. Ped., Vol. 93, No. 3, pp .535.

[76]. Henkin, R. I., Patten, B. M., Re, PK., Bronzett, D. A., (1975) : A syndrome of acute zinc loss, Arch Neurol, Vol. 32, No. 11, pp. $\quad 745-751$.

[77]. Dresti, I. E. (1984) : Zinc in the central nervous system : The emerging interactions. In : The Neurobiology of Zinc Part A. Edited by Frederickson, C. J., Howell, G. A. and Kasarskis, E. J., Alan R. L., New York, pp. 1-26.

[78]. Fairbanks, V. F., Fahey, J. L. and Beutler, E. (1971) : Clinical disorders of Iron metabolism, $2^{\text {nd }}$ ed., Grune and Stratton, New York, pp. 1-486.

[79]. Mc Cance and Widdowson, E. M. (1937) : Absorption and excretion of iron, Lancet, Vol. 2, pp. 680-684. 
Sanjeev Kumar, Reena, Mittal, Sweety and D. C. Jain; Role of Trace Elements in Duchenne Muscular Dystrophy, Journal of Biomedical Engineering and Medical Imaging, Volume 1, No 5, Oct (2014) , pp 71-112

[80]. Gramick, S. (1946) : Ferritin IX. Increase of the protein apoferritin in the gastrointestinal mucosa as a direct response to iron feeding. The function of ferritin in the regulation of iron absorption, J. Biol. Chem. Vol. 164, pp. 737-746.

[81]. Moore, C. V., Doan, C. A. and Arrowsmith, W. R. (1937) : Studies in iron transportation and metabolism, mechanism of iron transportations : Its significance in iron utilization in anemic states of varied etiology. J. Clin. Invest., Vol. 16, No. 4, pp. 627-648.

[82]. Mahler, H. R. and Elowe, D. G. (1953) : DPNH cytochrome reductase, a ferroflavo protein, J. Amer. Chem. Soc., Vol. 75, pp. 5769-5770.

[83]. Richert, D. A. and Westerfeld, W. W.(1954) : The relationship of iron to xanthime oxidase, J. Biol. Chem., Vol. 209, pp. 179-189.

[84]. Fisher, H. and Zeile, K. (1929) : Synthesis of hematoprophyrin, protoporphyrin and hemin, Ann. European Journal of Organic Chemistry, Vol. 468 , No. 1, pp. 98-116.

[85]. Ingram, D. J. E., Gibson, J. F. and Perutz, M. F. (1956) : Orientation of the four heme groups in hemoglobin, Nature, Vol. 178, pp. 906-908.

[86]. Holmberg, G. C. and Laurell, C. B. (1947) : Investigations in serum copper I. Nature of serum copper and its relation to the iron-binding protein in human serum. Acta Chem. Scand. Vol. I, pp. 944-950.

[87]. Schade, A. L., Reinhart, R. W., and Levy, H., (1949) : Carbon dioxide and oxygen in complex formation with iron and siderophilin, the iron-binding compound of human plasma, Arch Biochem., Vol. 20, No. 1, pp. $170-172$.

[88]. Lipschitz, D. A., Cook, J. D. and finch, C. A., (1974) : A clinical evaluation of serum ferritin as an index of iron stores. New. Eng. J. Med., Vol. 290, pp. 1213-1216.

[89]. Simes, M. A., Addiego, J. E., Jr., and Dallman, P. R., (1974) : Ferritin in serum : Diagnosis of iron deficiendcy and iron overload in infants and children, Blood, Vol. 43, No. 4, pp. 581-590.

[90]. Aikawa, J. K. (1971) : The relationship of magnesium to diseases in domestic animals and in human, Charles C. Thomas. Springfield, Illinois, pp. 1-145.

[91]. Aikawa, J. K. (1976) : Biochemistry and physiology of magnesium. In: Trace Elements in Humans : Health and diseases, Vol. II, Edited by Prasad, A. S., .Academic Press, New York, pp. 47-78.

[92]. Widdowson, E. M., McCance, R. A. and Spray, C. N. (1951) : The clinical composition of the human body, Clin. Sci., Vol. 10, pp. 113-125.

[93]. Waterlow J.C. ( 1992) : Endocrine changes in severe PEM .In: Protein-Energy Malnutrition, Edited by Waterlow, J. C., London, Edward Arnold, pp. 112-125.

[94]. Classen, H. G., (1984) : Magnesium and potassium deprivation and supplementation in animals and man : aspects in view of intestinal absorption. Magnesium, Vol. 3, No. 4-6, pp. 257-264.

[95]. Al-Ghamdi, S. M., Cameron, E. C., and Sutten, R. A., (1994) : Magnesium deficiency : Pathophysiologic and Clinical Overview, Am. J. Kidney. Dis., Vol. 24, No. 5, pp. 737-752. 
[96]. Wester, P. (1987) : Magnesium, Am. J. Clin. Nutr., Vol. 45, Supplement, pp. 1305-1312.

[97]. Krasner, B. (1979) : Cardiac effects of magnesium with special reference to anaesthesia : a rewiew, Can Anaesth Soc J., Vol. 26 No. 3, pp. 181-185.

[98]. Furukawa, Y., and Chiba, S., (1981) : Effects of magnesium on the isolated, blood-perfused atrial and ventricular preparations of the dog heart, Jpn. Heart. J.,Vol . 22, No. 2, pp. 239-246.

[99]. Stark, G., Stark, U., Pilger, E., Honigl, K., Bertuch, H. and Tritthart, H. A., (1989): The influence of elevated Mg2+ concentrations on cardiac electrophysiological parameters, Cardiovasc. Drugs. Ther., Vol. 3, No. 2, pp. 183-189.

[100]. Haigney, M.C.P., Berger, R., Schulman, S., Gerstenblith, G. ,Tunin. C Silver, B., Silverman, H. S., Tomaselli, G and Calkins, H (1997) : Tissue magnesium levels and the arrhythmic substrate in humans, J Cardiovasc Electrophysiol.,Vol. 8, No. 9, pp. 980-986.

[101]. Ireland, P., and Fordtran, J. S., (1973) : Effect of dietary calcium and age on jejunal calcium absorption in humans studied by intestinal perfusion, J. Clin. Investig., Vol. 52, No. 11, pp. 2672-2681.

[102]. Heaney, R. P., Saville, P. D., and Recker, R. R., (1975) : Calcium absorption as a function of calcium intake, J .Lab. Clin Med.,Vol. 85, No. 6, 881-890.

[103]. Wilkinson, R. (1976) : Absorption of calcium, phosphorus and magnesium calcium phosphate and magnesium metabolism. Edited by Nordin, B. E. C., Edinberg, Churchill Livingstone, pp. 36-112.

[104]. Marshall, D. H. (1976) : Calcium and phosphate kinetics calcium, phosphate and magnesium metabolism. Edited by Nordin, B. E. C. Edinberg, Churchill Livingstone, pp. 257-297.

[105]. Morris, H. A., Need, A. G., Horowitz, M., O'Loughlin, P. D., and Nordin, B. E., (1991): Calcium absorption in normal and osteoporotic postmenopausal women, Calcif. Tissue. Int., Vol. 49, No. 4, pp. 240-243.

[106]. Ebeling, P. R., Yergey, A. L. and Vleira, N.E. (1994) : Influence of age on effects of endogeneous 1, 25dihydroxyvitamin D on calcium absorption in normal women, Calcif .Tissue. Int., Vol. 55 , No. 5 , pp. 330-334.

[107]. Need, A. G., Morris, H. A., Horowitz, M., Scopacasa, E. and Nordin, B. E., (1998): Nordin. Intestinal calcium absorption in men with spinal osteoporosis, Clin. Endocrinol., Vol. 48 , No. 2, pp. 163-168.

[108]. Nordin, B. E. C. (1976) : Nutritional considerations in : Calcium, phosphate and magnesium metabolism. Edited by Nordin, B. E. C., Edinberg, Churchill Livingstone, pp. 1-35.

[109]. Kent, G. N., Price, R. I., and Gutteridge, D. H., Allen, J. R., Barnes, M.P., Hickling, Retallack, R. W., Wilson, S.G., Delvin, R.D., Price, R.I., Simith, M., Bhagat, C.I., Davies, C, St. Johns, A., (1990) : Human lactation : forearm trabecular bone loss, increased bone turnover, and renal conservation of calcium and inorganic phosphate with recovery of bone mass following weaning, J. Bone. Miner. Res., Vol. 5, No. 4, pp. 361-369.

[110]. Lopez, J. M., Gonzalez, G., Reyes, V., Campino, C. and Diaz, S. (1996): Bone turnover and density in healthy women during breastfeeding and after weaning, Osteoporos. Int., Vol. 6, No. 2, pp. 153-159. 
Sanjeev Kumar, Reena, Mittal, Sweety and D. C. Jain; Role of Trace Elements in Duchenne Muscular Dystrophy, Journal of Biomedical Engineering and Medical Imaging, Volume 1, No 5, Oct (2014) , pp 71-112

[111]. Chan, G. M., McMurray, M., Westover, K., Engelbert-Fenton, K., and Thomas, M. R., (1987): Effects of increased dietary calcium intake upon the calcium and bone mineral status of lacting adolescent and adult women, Am. J. Clin. Nutr., Vol . 46, No. 2, pp. 319-323.

[112]. Katz, M., and Steihm, E.R. (1977): Host defense in malnutrition. Pediatr. Vol. 59, No. 4, pp. 490-495.

[113]. Suskind, R.M. (1977): Malnutritian and the immune response In: Kroc foundation Series, Vol. 7, New York, USA, Raven Press, PP 468.

[114]. Bongiorni-Malave, I.B. and Pocino, M. (1980) : Abnormal regulatory control of the antibody response to hetrologous erythrocytes in protein-calorie-malnourished mice, Clin. Immunol. Immunopathol., Vol. 16 No. 1 , pp. 19-29.

[115]. Malave, I., Nemeth, A. and Pocino, M., (1980) : changes in lymphocyte populations in proteinscaloriedefieient mice, Cellular, Vol. 49, No. 2, pp. 235-249.

[116]. Gershwin, M. E., Keen, C. L., Fletcher, M. P. and Hurley, L. S. (1988): Trace element deficiencies and immune responsiveness. In : Trace elements in man and animals, Edited by Hurley, L. S, Keen, C. L. Lonnerdal, Bo, and Rucker, R. B, Plenuum press, New York and London, pp. 85-89.

[117]. Rigas, D. A., Rigas, E. C. and Head, C., (1979) : Biophasic toxicity of diethyldithiocarbamate, a metal chelator, to T leymphocytes and polymorphonucuclear granulocytes : Reversal by zinc and copper Biochem. Biophys. Res. Commun. Vol. 88, No. 2, pp. 373-379.

[118]. Walten, W. S. and Richard, N. P. Jr. (2003) : Elements metabolism and body composition, Mol. Nucl. Med. in press, pp. 253-300.

[119]. Malcolm, J. J., David, A. J. and Richard, H. T. E. (1985) : Measurements of calcium and other elements in muscle biopsy samples from patients with Duchenne muscular dystrophy, Vol. 147, No. 3, pp. $215-221$.

[120]. Allen, D. G., Gervasio, O. L., Yeung, E. W. and Wheitehead, M. P. (2010) : Calcium and the damage pathways in muscular dystrophy. Can. J. Pysoiol. Pharmacol., Vol. 88, No. 2, pp. 83-91.

[121]. Imbert, N., Cognard, C., Duport, G., Guillou, C. and Raymand, G. (1995) : Abnormal calcium homeostasis in Duchenne muscular dystrophy myotubes contracting in vitro, Cell. Calcium, Vol. 18, No. 3, pp. 177-86.

[122]. Rena, Y. and Yael, H. (1978) : Elements in muscle measured and in vitro with X-ray spectrometry. Muscle and Nerve., Vol. 1, No. 6, pp. 486-494.

[123]. Caroline, A. M., Raphael, G., Rena, Y. and Victor, D. (1980) : Elements analysis of skeletal muscle in Duchenne muscular dystrophy using X-ray fluorescence spectrometry, Muscle \& Nerve, Vol. 3, No. 6, pp. 502508.

[124]. Hisao, K., Mieko, K. and Yashinori, I. (1991) : Manganese, Copper, Zinc and Iron concentrations and subcellulor distribution in two types of skeletal muscle., Exp. Biol. Med., Vol. 196, No. 1, pp. 83-88.

[125]. Turner, P. R., Fong, P. Y., Denetclaw, W. F. and Steinhardt, R. A. (1991) : Increased calcium influx in dystrophic muscle. JCB, Vol. 115, No. 6, pp. 1701-1712. 
[126]. Arthur, J. R. and Duthie, G. G. (1994) : Free radicals and trace elements in muscle disorders and sporis, In : Trace elements and free radicals in oxidative disease, edited by Favier, A. E., Neve, J. and Faure, P. AOCS Press, U. K., pp. 241-248.

[127]. Baharch, M., Jay, R. M. and Mark, A. T. (2005) : Nutritional inadequacy in adults with muscular dystrophy, Muscle \& Nerve, Vol. 31, No. 6, pp. 713-718.

[128]. Kando, H., Miura, M., Nakagaki, I., Sasaki, S., and Itokawa, Y. (1992) : Trace element movement and oxidative stress in skeletal muscle atrophied by immobilization, Am. Physiol. Soc. Vol. 262, No. 5 pt 1, pp. E583-90..

[129]. Gage, V. H., Drori, J. B., Franklin, D. and Schwartz, (1970) : Hypokalemic myopathy and elevation of serum enzymes, Arch. Neurol., Vol. 22, No. 4, pp. 335-341.

[130]. Howard, M. K., William, D. S., and Robert, N. R. (1983) : Malignant hyperthermia in a child with Duchenne muscular dystrophy, Pediatrics, Vol. 71, No. 1, pp. 118-119.

[131]. William, B., Benedict, C. and Muriance, L. (1963) : Body Potassium content in patients with muscular dystrophy, Anals. N. Y. Acad. Sci., Vol. 110, pp. 282-290.

[132]. Kassmann, R. J., Dorothy, C., Peterson, B. S., and Howard, L. A. (1965) : Studies in neuromuscular disease, Neurology, Vol. 15, No.9, pp. 855.

[133]. Hull, K. L. and Roses, A. D. (1976) : Stoichiometry of sodium and potassium transport in erythrocytes from patients with mytonic muscular dystrophy. J. Physiol., Vol. 254, pp. 169-181.

[134]. Edmonds, C. J., Smith, T., Griffiths, R. D., Mackenzie, J. and Ed. Wards, R. H. (1985) : Total body potassium and water, and exchangeable sodium in muscular dystrophy. Clinical. Science, London. Vol. 68, No. 4, pp. 379-85.

[135]. William, H. B., Marianne, L. and Benedict, C. (1967) : The significance of decreased body potassium concentrations in patients with muscular dystrophy and non dystrophic relatives, New. Engl. J. Med., Vol. 276, pp. 1349-1352.

[136]. Rowland, L. P., Layzar, R. S. and Kagen, L. J. (1968) : Lack of some muscle proteins in serum of patients with Duchenne dystrophy. Arch. Neurol, Vol. 18, No. 3, pp. 272-276.

[137]. Hopf, F. W., Turner, P. R. and Steinhardt, R. A. (2007) : Calcium misregulation and the pathogenesis of muscular dystrophy, Sub Cel. Biochem., Vol. 45, pp. 429-464.

[138]. Neve, J. (2005) : Selenium : An essential micronutrient with extended biological potency at supra-nutritional intakes, Trace elements in medicine Vol.6,No. 2, pp. 15-20.

[139]. Westermarck, T. and Atroshi, F. (2005) : Dietary approaches to patients with Duchenne muscular dystrophy (DMD), patients with spielmeyer-sergen disease, and patients with epilepsy, Trace elements in medicine, Vol. 6, No. 2, pp.27-32.

[140]. Alain, L., Mathieu, R., Alain, K., Pascale, G. and Valérie, A (2009): Selenoprotein function and muscle disease, Biochemica. Et Biophysica Acta, Vol. 1790, No. 11, pp. 1569-1574. 
Sanjeev Kumar, Reena, Mittal, Sweety and D. C. Jain; Role of Trace Elements in Duchenne Muscular Dystrophy, Journal of Biomedical Engineering and Medical Imaging, Volume 1, No 5, Oct (2014) , pp 71-112

[141]. Zunkley, H. (1988) : Clinical aspects of selenium metabolism, Biol. Trace. Elem. Res. Vol. 15, No. 1, pp. $139-146$.

[142]. Harris, L. S., Robert, L. F., and James, N. E. (1962) : Magnesium and calcium in human muscular dystrophy, Am. J. Dis. Child, Vol. 103, No. 6, pp. 771-776.

[143]. Samuel, W. B., Erik, J. O. Dorothy, F. and Edwin, R. H. (1965) : Plasma and erythrocyte magnesium in muscular dystrophy, Am. J. Dis. Child, Vol. 110, No. 2, pp. 172-175.

[144]. Tulio, E. B., Syamal, K. B., Genaro, M. A. P., Caroly, M. C., David, P. and Barbara, B. (1982) : Muscle calcium and magnesium content in Duchenne muscular dystrophy. Neurology, Vol. 32, No. 10, pp. 1088-1092.

[145]. Csenkér, E., Diöszeghy, P., Fekete, I., and Mechler, F. (1982) : Ion concentrations in serum and cerebrospinal fluid of patients with neuromuscular diseases, Arch. Psychiatry, Mervenkr, Vol. 231, No. 3, pp. 251-8.

[146]. Carlier, L., Legrand, M., Riviére, H. and Navarro, J. (1993) : Nutritional assessment in Duchenne muscular dystrophy, Dev. Med. Child. Neurol., Vol. 35, No. 12, pp. 1074-1082147.

[147]. Walsh, A.,(1956):The application of atomic absorption spectra to chemical analysis, Spectrochim.

Acta Vol. 7, pp. 108.

[148]. Skoog, D. A., Holler, F. J. and Nieman, T. A. (1998) : Prinicples of instrumental analysis, $5^{\text {th }}$ Edition. Harcourt Brace \& Company, Philadelphia. pp. 849.

[149]. John, H., Maxwell, J.D., Stewart, D.A., Parsons, V., Williams, R., (1971) : Altered calcium metabolism in epileptic children on anti-convulsants, British Medical Journal, Vol. 4, pp. 202-204.

[150]. Prasad, R., Singh, A., Das, B. K., Upadhyay, R. S., Singh, T. B., Mishra, O. P. (2009) : Cerebrospinal fluid and serum zinc copper, magnesium and calcium levels in children with idiopathic seizure, Journal of Clinical and Diagnostic Research, Vol. 3, No. 6, pp. 1841-1846.

[151]. Lech, T. (2001) : Calcium and magnesium content in hair as a predictor of disease in children, Trace Elements and Electrolytes,

Vol. 18 , No. 3, pp. 112-121.

[152]. Avci, H., Kizilkan, N., and Yaman, M., (2008) : Comparison of trace elements concentrations in scalp hair of epileptic and normal subjects, Trace Elements and Electrolytes, Vol. 25 , No. 3 , pp. 147-155.

[153]. Barlow, P.J., Francois, P.E., Goldberg, I.J. Richardson, I., Izmeth, M.G., Kumpeson, K., and Sykes, P., (1986) : Trace metal abnormalities in long stay hyperactive mentally handicapped children and agitates senile dements, J Royal Soc Medicine. Vol. 79, No. 10, pp. 581-583.

[154]. Khanna, R. S., Kumar, R., Asthana, R. K., Negi, R., Pande, D., Kumar, A. and Khanna, H. D. (2009) : Role of trace element and antioxidants in free radical mediated injury in neonates, MASAUM Journal of Basic and Applied Science, Vol. 1, No. 3, pp. 543-547.

[155]. Adnan, M., Ahmed, G., Khaled, O., Indress, A. M., Ahmed, A., Hiatham, T., Wall, H. (2010) : Simultaneous Determination of $\mathrm{Cd}, \mathrm{Pd}, \mathrm{Cu} \mathrm{Zn}$ and Se. In Human blood of Jordanian smokers, by ICP-OES, Biological Trace Element Research, Vol. 133, No. 1, pp. 1-11. 
[156]. Guidotti, T. L., McNamra, J., Moses, M. S., (2008) : The interpretation of trace element analysis in body fluids, Indian Journal of Med. Res., Vol. 128, pp. 524-532.

[157]. Deniz, T., Ali, H. T., Saraymen, R (2008) : The effects of antiepileptic drugs on serum and hair trace element levels, Ankara. Universitesi Tip. Fakultesi. Mecmuasi, Vol. 61, No.2, pp. 73-76.

[158]. Soylak, M., Saracoglu, S., Divrikli, U., and Elci, L., (2001) : Copper and zinc concentrations of serum samples of healthy people living in Tokat, Turkey, Trace Element and Electrolytes, Vol. 18, No.1, pp. 47-40.

[159]. Delves H. T., Clayton, B. E., and Bicknel, J., (1973) : Concentration of trace metals in the blood of children, Br. J. Prev .Soc. Med., Vol. 27, pp. 100-107.

[160]. Kumar, S., Bajaj, M., Jain, D.C. and Yadav, H. S. (1988) : A search for the trace elemental deficiencies in grand mal epilepsy using atomic absorption spectrophotometric technique and catalytic agent in the cellular enzyme reaction, Proc. World .Congress on Clinical. Nutrition, Vol. 1, pp. 115A-121A.

[161]. Smith, W. G., and Bone, I., (1982) : Copper, zinc and magnesium plasma levels in epilepsy, J Neurol Neur Surg Psychiatry, Vol. 45, No. 11 , pp. 1072- 1073.

[162]. Kaji, M., Ito, N., Okuno, T., Momoi, T., Sasaki, H., Yamanake, C., Yorifuji, T., and Mikawa, H. (1992) : Serum copper and zinc levels in epileptic children with valporate treatment, Epilepsia, Vol. 33, No. 3, pp. 555-557.

[163]. Kumar, S., Kumar, V., and Jain, D. C. and Mittal. R. (2013): Trace element analysis in epileptic children. Open.J . Appl .Sci , Vol. 3, No.3, pp. 449-476. 